\title{
Upper Cretaceous weakly to strongly silica-undersaturated alkaline dike series of the Mantiqueira Range, Serra do Mar alkaline province: Crustal assimilation processes and mantle source signatures
}

\author{
Rogério Guitarrari Azzone ${ }^{1 *}$, Excelso Ruberti ${ }^{1}$, Júlio César Lopes da Silva ${ }^{1}$, \\ Celso de Barros Gomes ${ }^{1}$, Gaston Eduardo Enrich Rojas ${ }^{1}$, \\ Maria Helena Bezerra Maia de Hollanda ${ }^{1}$, Colombo Celso Gaeta Tassinari ${ }^{1}$
}

\begin{abstract}
Three series of alkaline dikes are characterized in a restricted area of the Mantiqueira Range: a weakly silica-undersaturated series (normative ne < 7), of potassic character, represented by basanite, tephrites, alkali basalts, basaltic trachyandesites, phonotephrites, tephriphonolites, and trachyandesites, an intermediate series ( 7 > normative ne > 13), of potassic character, consisting only of basanites and tephrites, and a strongly silica-undersaturated series (normative ne > 13), of sodic character, consisting of basanites, tephrites, phonotephrites, and phonolites. Ar-Ar data for biotite from a tephriphonolite dike yielded an average age of $85.4 \pm 0.4 \mathrm{Ma}$. All three series show similar evolution trends controlled mainly by early-fractionation of olivine, spinel and clinopyroxene and, secondly, fractionation of plagioclase and apatite. Different degrees of crustal assimilation are suggested for each series. Assimilation processes are responsible for the wide ${ }^{87} \mathrm{Sr}^{86} \mathrm{Sr}_{i}(0.70447-0.71172)$ and $\left.{ }^{143} \mathrm{Nd}\right|^{144} \mathrm{Nd}_{i}(0.51237-0.51244)$ ranges, for the increased $\mathrm{K}_{2} \mathrm{O} / \mathrm{Na}_{2} \mathrm{O}, \mathrm{Ba} / \mathrm{Sr}$ and $\mathrm{Rb} / \mathrm{Sr}$ ratios, and for the reduced Ce/Pb ratios. In general, a significant contribution from partially melted host rocks is associated to the weakly silica-undersaturated potassic series. A phlogopite-bearing carbonate-metasomatized heterogeneous peridotite source accounts for the main chemical variations in the least contaminated samples of each series. Geochemical signatures of the strongly sodic alkaline series indicate a greater contribution from carbonated pyroxene-rich veins in the mantle source.
\end{abstract}

KEYWORDS: alkaline magmatism; potassic and sodic series; crustal assimilation; metasomatized mantle source.

\section{INTRODUCTION}

Cogenetic association of contrasting strongly and weakly alkaline magmatic series is a common feature of many magmatic provinces (e.g., Wilson et al. 1995, Fitton \& Upton 1987, Comin-Chiaramonti et al. 1997). Several factors seem to contribute with their differences in magma composition. Small variations in the degree of partial melting of a common source, distinct degrees of crustal assimilation and/or variable physicochemical conditions of crystallization from similar parent melts, and heterogeneous mantle source metasomatism have all been attributed to classical occurrences such as the Hawaiian alkaline volcanism (Clague 1987), the Cantal volcano, the Massif Central (Wilson et al. 1995), the Teide-Pico Viejo volcanic complex, the Canary Islands (Ablay et al. 1998), and the East African Rift System (Furman \& Graham 1999).

The Serra do Mar alkaline province (SMAP; Almeida 1983, Thompson et al. 1998, Brotzu et al. 2005), southeastern Brazil, consists of Upper Cretaceous to Paleogene plutonic complexes and dike swarms formed by magmas of varied degrees of evolution from potassic primitive parental

IInstituto de Geociências, Universidade de São Paulo - USP, São Paulo (SP), Brazil.E-mails: rgazzone@usp.br,exrubert@usp.br, jlopes16@usp.br, cgomes@usp.br gastonenrich@usp.br,hollanda@usp.br,ccgtassi@usp.br

*Corresponding author.

Manuscript ID: 20170089. Received in: 08/07/2017. Approved in: 10/31/2017 
compositions. Brotzu et al. (2005) distinguished two main potassic suites for the dike swarms of the province: a more widespread, strongly silica-undersaturated suite that ranges from ultrabasic to phonolitic rocks, and a weakly silica-undersaturated suite that ranges from basalts to trachytes. Distinct basanite and foidite parental magmas are assigned to the strongly silica-undersaturated suite. Although the evolution of both suites involved fractional crystallization and crustal assimilation, a heterogeneous metasomatized mantle source is believed to be the main control factor in their generation. Despite their regional character, both potassic suites of alkaline magmas are found locally in SMAP. Bennio et al. (2002) described a strongly silica-undersaturated tephriphonolite to phonolite series and a weakly silica-undersaturated to saturated trachyandesite-trachyte series in the Arraial do Cabo Frio peninsula, a restricted area at the far eastern coast of Rio de Janeiro. Scarce local basanites and trachybasalts are suggested as the main parental melts for both series (Bennio et al. 2002).

In this paper, three distinct magmatic series that occur mainly as dikes are reported for the first time in a limited area of the Mantiqueira Range, a small part of the overall Serra do Mar province: a strongly-alkaline sodic dike series, a weakly-alkaline potassic dike series, and an intermediate potassic series. New petrographic, mineral chemistry, geochemical and radiogenic isotopic data are presented. Fractional crystallization, crustal assimilation and possibly mantle source mineralogy differences are deemed responsible for the generation of the series. New Ar-Ar biotite radiometric ages for this magmatic event are also shown.

\section{MAGMATIC CONTEXT / REGIONAL GEOLOGY}

Mesozoic to Cenozoic alkaline and alkaline-carbonatitic occurrences are known in the southern-central portion of the Brazilian Platform, being grouped into several provinces by Ulbrich and Gomes (1981), Almeida (1983) and Riccomini et al. (2005). The Upper Cretaceous to Paleocene alkaline intrusions (less than $100 \mathrm{~km}^{2}$ each) and subordinate dikes (Morbidelli et al. 1995, Gomes \& Comin-Chiaramonti, 2005) found on the coasts of Saao Paulo and Rio de Janeiro, and in the Mantiqueira Range fall within the SMAP (cf. Brotzu et al. 2005 and Thompson et al. 1998; Fig. 1A), intruding Neoproterozoic rocks of the Ribeira and Brasília belts (Heilbron et al. 2004). In these suites, the abundance of evolved types, mostly nepheline syenites and syenites, is remarkable, as reported by several authors (e.g., Bellieni et al. 1990, Brotzu et al. 1992, 1997, 2007, Ulbrich et al. 2005, Gomes et al. 2017, Enrich et al. 2009, Rosa \& Ruberti 2017,
Melluso et al. 2017), in the São Sebastião, Búzios and Monte de Trigo Islands and Morro de São João, Itatiaia and Poços de Caldas, for example. On the other hand, the Ponte Nova alkaline mafic-ultramafic massif is the only known intrusive suite with prevalence of mafic to ultramafic cumulate rocks (Azzone et al. 2009, 2016). Dike swarms associated with the complex usually include more primitive, basic alkaline rocks (Alves et al. 1992, Garda et al. 1995, Valente 1997, Thompson et al. 1998, Brotzu et al. 2005, 2007, Azzone et al. 2009, Enrich et al. 2009).

The Mantiqueira Range consists of Brasilia belt rocks, mainly of the Socorro-Guaxupé nappe, and rocks of the Embu terrane (Vinagre et al. 2014a, 2014b). In Sapucaí Mirim, Santo Antônio do Pinhal and Campos do Jordão, their main outcrops correspond to metasyenogranites, metamonzogranites and biotite gneisses of the Serra da Água Limpa batolith (645-630 Ma, Vinagre et al. 2014a) (Fig. 1B). Metasedimentary rocks of the Embu terrane are only found in a restricted sector (Vinagre et al. 2014a), consisting of quartzites with some intercalations of biotite schists. Serra da Água Limpa rocks indicate intermediate P (5-6 kbar) and high-T metamorphism from amphibolite to granulite facies (Vinagre et al. 2014b). In the Upper Cretaceous, the batholith experienced exhumation to upper crust levels, as indicated by thermochronological studies based on apatite fission tracks (Tello-Saenz et al. 2003).

The Upper Cretaceous alkaline intrusions that occur in the Mantiqueira Range nearby Sapucaí Mirim, Santo Antônio do Pinhal and Campos do Jordão are exclusively related to the Ponte Nova cumulatic mafic-ultramafic alkaline massif and its associated dikes (Fig. 1B). In general, most dikes, identified as alkaline lamprophyres, are thought to represent alkaline basalt, basanite, tephrite and nephelinite magmas. However, a complete alkaline series towards phonolite melts is also recognized (Alves et al. 1992, Thompson et al. 1998, Azzone et al. 2009, 2016).

\section{GEOLOGY}

Several authors report the presence of dikes of alkaline affinity in Campos do Jordão, a region in the Mantiqueira Range (e.g., Melcher \& Melcher 1972, Alves 1978, Cavalcante et al. 1979, Alves et al. 1992, Thompson et al. 1998, Azzone et al. 2009, Menezes et al. 2015). The information presented by them regards mainly geologic and petrographic aspects of these occurrences.

In situ mesocratic to melanocratic alkaline dikes outcrop on many sites along SP-123 road, from Campos do Jordão to Santo Antônio do Pinhal, and even the Ponte Nova Massif neighborhood in the city of Sapucaí Mirim. 
The dikes, which represent either single magma pulses or multiple intrusions, appear as steeply dipping, 0.2 to $1.0 \mathrm{~m}$ thick dark gray to black intrusions. Zonation is present in most cases, with macrocryst-rich cores and a fine-grained matrix that grades to macrocryst-poor rims in an aphanitic matrix. An NE-trending direction prevails for the dikes intruding the Serra da Água Limpa batholith. A NW-trend is prevalent in the bodies that intrude the Ponte Nova massif neighborhood. Although fresh rock outcrops are scarce, unaltered samples could be collected from blocks found in the highlands drainage system, without zonality control.

Leucocratic to hololeucocratic dikes and sills are also present in the Ponte Nova massif neighborhood and, similarly to the mesocratic to melanocratic bodies, they intrude the alkaline body and the Serra da Água Limpa batholith. Apparently, they are more abundant near the massif. In some cases, tabular bodies evolve to irregular brecciated zones rich in country rock fragments. Phonolites, the most evolved
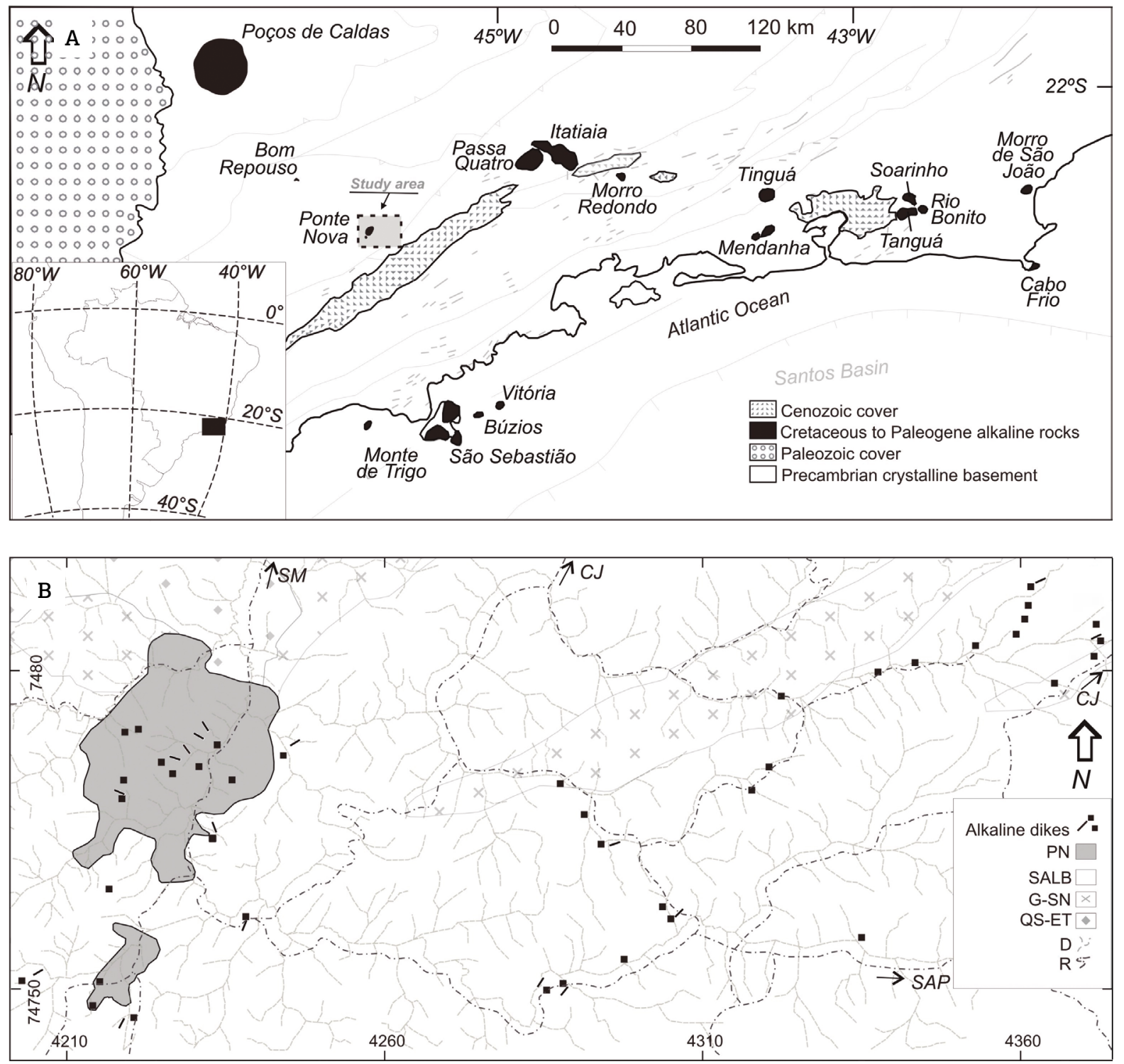

Figure 1. (A) Geological sketch map of the Serra do Mar alkaline province in southeastern Brazil, modified from Thompson et al. (1998). In the gray rectangle, the studied area. (B) Simplified geological map of part of the Mantiqueira Range. Alkaline dikes are represented by black squares (sampling point of fresh rocks) in the main drainage segments and by the strike direction of in situ bodies. PN, Ponte Nova alkaline massif (Azzone et al. 2009); SALB, Serra da Água Limpa batolith; G-SN, gneisses of the Socorro nappe; QS-ET, quartzites and schists of Embu terrane (Precambrian basement units from Vinagre et al. 2014a). R, main roadways; D, drainages. Reference Cities: SAP, Santo Antônio do Pinhal; CJ, Campos do Jordão; SM, Sapucaí Mirim. 
rock type present, commonly intrude Precambrian rocks. Rounded xenoliths of syenogranite are irregularly found in the leucocratic dikes and sills, with diffusion rings in an aphanitic matrix, which, at least in a local scale, indicates assimilation processes.

\section{PETROGRAPHY}

The mesocratic to melanocratic alkaline dikes in the study area are mainly panidiomorphic porphyritic, with a fine-grained to aphanitic matrix, being identified mostly as alkaline lamprophyres ("camptonites", "monchiquites" and "sannaites", cf. Le Maitre 2002). The coarse- to medium-grained macrocryst population ranges from $>5$ to $<20 \mathrm{vol} . \%$, mainly consisting of clinopyroxene and olivine with subordinate kaersutite. Clinopyroxene is the most important macrocryst in most bodies. Several populations of clinopyroxene macrocrysts are represented by hedenbergite, diopside or Ti-augite cores, all exhibiting corrosion textures and oscillatory and/or step zoning. Titanaugite rims are also present. Glomeroporphyritic textures formed mainly by medium- to coarse-grained clinopyroxenes are recognized in some occurrences. Olivine macrocrysts, when not replaced by low-grade deuteric/hydrothermal-related serpentine, carbonates and muscovite aggregates, present normal zoning, with contrasting thin rims lower in forsterite molecules. In some dikes, olivine macrocrysts show gulf corrosion textures with biotite coronas, whereas in others sites they are completely euhedric. Minor inclusions of Chromite and Cr-spinel are found in some olivine macrocrysts. Kaersutite macrocrysts are less common, displaying normal step zoning, sometimes evolving to pargasite compositions. This lamprophyre assemblage cannot simply be said to form phenocrysts, but it could be interpreted mainly as an assemblage of antecrysts and even xenocrysts. Disequilibrium microtextures are representative of complex plumbing systems, as reported for similar occurrences (e.g., Menezes et al. 2015, Ubide et al. 2012, 2014). Their matrices are basically composed of Ti-augite, plagioclase, kaersutite to pargasite, Ti-magnetite, alkali feldspar, biotite, apatite, and analcime. Very fine-grained elongated alkali feldspar grains and equivalent amounts of interstitial analcime constitute the felsic mesostasis, possibly related to volatile-rich late magmatic or hydrothermal glass alteration. Ameboid- to globular-shape structures (ocelli) disseminate through the lamprophyres, consisting mainly of carbonates and/or analcime. Rounded centimetric xenoliths of the metasyenogranitic host rock are occasionally found. Some dikes are mineralogically similar to lamprophyres. However, in addition to a coarser matrix, they also contain minor amounts of plagioclase in the macrocryst population. Petrographically, these rock types, which are identified as tephrites, could represent a shortly evolved stage of the lamprophyre family.

Leucocratic to hololeucocratic alkaline dikes and sills are mostly fine-grained to aphanitic in texture, but sometimes porphyritic with medium to coarse-grained macrocrysts, in gray to dark green colors. Phonolites are hololeucocratic and typically exhibit porphyritic texture, with alkali feldspar as the most important macrocryst, and subordinate nepheline. Their matrices are predominantly fine-grained to aphanitic, mainly formed by tabular alkaline feldspar and euhedral to interstitial nepheline arranged in a trachytic to fluidal texture. Acicular aegirine is the main mafic phase, with minor amounts of amphibole and apatite. Trachytes, tephritic phonolites and phonolitic tephrites are also found in the study area. These rocks are fine- to medium-grained inequigranular, with greater amounts of tabular plagioclase, pargasite and Ti-biotite. They lack aegirine, and their alkaline feldspar, opaque minerals, apatite and nepheline contents are lower than in the phonolites. In some of these intermediate varieties, clusters of coarse-grained plagioclase are also identified, configuring a glomeroporphyritic texture. In other cases, apatite and biotite are medium-grained macrocrysts set in a felsic fine-grained matrix.

\section{ANALYTICAL METHODS}

Mineral and whole-rock analyses were carried out at geoanalytical facilities in the Institute of Geosciences, University of São Paulo (GeoAnalítica-USP). A Jeol JXA8600 electron microprobe was used in the analysis of clinopyroxene, olivine, amphibole and biotite, at an acceleration potential of $15 \mathrm{kV}$, a probe current intensity of 20 $\mathrm{nA}$, and a beam diameter of approximately $5 \mu \mathrm{m}$. Silicate minerals and synthetic oxides were employed as standards, data being corrected online using the PROZA software (Bastin et al. 1984). Whole-rock major element and some trace element analyses were performed on fused glass discs and pressed powder pellets according to analytical methods described by Mori et al. (1999) using a Philips PW 2400 $\mathrm{X}$-ray fluorescence spectrometer. Weight loss on ignition (LOI) was evaluated by standard gravimetric techniques (Mori et al. 1999). Whole-rock trace elements and rareearth elements were analyzed with a Perkin Elmer ELAN 6100DRC ICP-MS, following procedures described by Navarro et al. (2008).

All isotope analyses were carried out at the geochronological research center at University of São Paulo. Whole-rock $\mathrm{Sr}$ and $\mathrm{Nd}$ isotope composition analyses 
were performed by conventional ion exchange chromatography combined with thermal ionization mass spectrometry (TIMS) following the analytical procedures published in Souza (2009) and Petronilho (2009). For ${ }^{40} \mathrm{Ar} /{ }^{39} \mathrm{Ar}$ dating, samples were irradiated for 24 hours using the IEA-R1 nuclear reactor. Isotope analyses were performed by incremental heating with an ARGUS VI (Thermo Scientific) mass spectrometer. Gas extraction and purification were made with a $\mathrm{Nd}: \mathrm{YVO}_{4}$ laser connected to an ultrahigh vacuum cleanup line (SAES-GP50). Data reduction, including correction for nuclear and background interferences, mass discrimination, J-value determination and graphical representation were all processed with the ArArCALC software (Koppers 2002). ${ }^{40} \mathrm{Ar} /{ }^{39} \mathrm{Ar}$ ages were measured in relation to the flux monitor standard Fish Canyon (28.01 $\pm 0.04 \mathrm{Ma}$; Phillips \& Matchan 2013). Plateau ages consider $\geq 50 \%$ of ${ }^{39} \mathrm{Ar}$ released over at least three continuous steps overlapping at a $95 \%$ confidence level.

\section{RESULTS}

\section{Mineral chemistry}

The composition of the main mafic minerals (Suppl. Tab. A1), which confirms the alkaline character of all occurrences, is in accordance with the conclusions of Brotzu et al. $(2005,2007)$ in that mineral chemical trends are very similar to those of various Upper Cretaceous SMAP occurrences. Olivine macrocrysts are $\mathrm{Mg}$-rich $\left(\mathrm{Fo}_{87-73}\right)$, with very low $\mathrm{Ni}$ (up to $0.005 \mathrm{apfu}$ ) and $\mathrm{CaO}$ (up to $0.01 \mathrm{apfu}$ ). Clinopyroxenes constitute the chief mafic phase in all bodies and are associated with early (macrocrysts) and late (matrix) magmatic stages. Although displaying well-defined optical zonation, their compositions are mainly expressed as a variation of a diopside-hedenbergite solid solution series $\left(\mathrm{Wo}_{53-41} \mathrm{En}_{46-23} \mathrm{Ae}_{1-13}\right)$, with late stages enriched in the Fs member (Fig. 2A). Earlystage compositions are very similar to those of the Ponte Nova massif (Azzone 2008). The evolution trend is similar to the initial part of Passa Quatro massif and amphibole-free rocks of the Búzios Island (Brotzu et al. 1992, 1997, Gomes et al. 2017) (Fig. 2B). Amphiboles represent a trend of kaersutite compositions, grading toward pargasite and magnesian hastingsite end members (cf. Leake et al. 1997) (Fig. 2C) similar to that reported for the Ponte Nova massif (Azzone 2008). All biotite crystals belong to the phlogopite-annite series (Tischendorf et al. 2007), and the main compositions are concentrated in the Ponte Nova field (Fig. 2D, Azzone 2008).

\section{Geochemistry}

Different alkaline dike series are distinguished in the Mantiqueira Range (Fig. 3A). Although the petrographic character of the most primitive types does not allow for the recognition of clear patterns or mineral sequences, whole-rock geochemical data combined with data on intermediate and more evolved types suggest that three magmatic series could be characterized in the region based on normative nepheline content (Suppl. Tabs. A2-A4)). A weakly silica-undersaturated series (WAS; normative ne $<7$ ) of potassic character is represented by basanite, tephrites, alkaline basalts, basaltic trachyandesites, phonotephrites, tephriphonolites, and trachyandesites (Suppl. Tab. A2). A potassic intermediate series (IS; 7 >normative ne > 13) consists only of basanites and tephrites (Suppl. Tab. A3). A sodic, strongly silica-undersaturated series (SAS; normative ne> 13) consists of basanites, tephrites, phonotephrites, and phonolites (Suppl. Tabs. A4 and A5). Dikes cutting the Ponte Nova massif are mainly associated with the WAS series, whereas dikes intruding the Precambrian basement near Campos do Jordão belong to the SAS series.

Similar compositional trends were found for the aforementioned series. The mineralogical control of the bulk-chemical composition of the three series and their variable $\mathrm{SiO}_{2}-$ undersaturation degrees are highlighted in a $\mathrm{R}_{1}-\mathrm{R}_{2}$ diagram (Fig. 3C). All series are basically controlled by early fractionation of clinopyroxene and olivine in a similar way as observed near the Ponte Nova massif, with significant amounts of cumulate rocks (Azzone et al. 2016). The dikes described in the region by Thompson et al. (1998) are not considered representative of the compositional trends discussed in this study. Phonolites are representative of extremely fractionated peralkaline magmas (A.I. > 1.0, Suppl. Tab. A5).

An almost analogous pattern of incompatible element enrichment is presented in WAS, IS and SAS (phonolites excluded) diagrams (Figs. 4A to 4D). However, whole-rock compositions for SAS diagrams are characterized by well-defined positive anomalies of $\mathrm{Ba}, \mathrm{Sr}$ and well-defined negative anomalies of $\mathrm{K}, \mathrm{Pb}, \mathrm{Ti}, \mathrm{Zr}$ and $\mathrm{Hf}$ in primitive-mantle normalized spidergrams (Fig. 4C). The IS and WAS series, instead, display progressive enrichments in $\mathrm{Rb}, \mathrm{K}, \mathrm{Pb}, \mathrm{U}$ and Ti (Figs. 4A and 4B). Due to their extremely fractionated compositions, phonolites exhibit positive anomalies of $\mathrm{Nb}, \mathrm{Zr}, \mathrm{Hf}, \mathrm{Pb}$ and $\mathrm{Rb}$ and negative anomalies of $\mathrm{Ba}, \mathrm{Sr}$ and Ti (Fig. 4D).

The distribution chondrite-normalized REE values shows a relatively linear behavior for all three series (Fig. 5), featuring a more conspicuous enrichment in LREE (about 100-600 times) than in HREE (about 10-50 times). Also, REE contents are not much different, except for the higher enrichment of the most primitive SAS. Phonolites, however, 
show greater LREE enrichment and higher depletion in intermediate REE, in an upward concave-shape pattern with HREE levels more enriched than those of intermediate-REE.

\section{Sr and Nd Isotopes}

Whole-rock initial isotopic ratios $\left({ }^{87} \mathrm{Sr} /{ }^{86} \mathrm{Sr}_{\mathrm{i}}\right.$ and ${ }^{143} \mathrm{Nd} /{ }^{144} \mathrm{Nd}$ ) for each series of the Mantiqueira Range are listed in Supplementary Tables A2-A5. Values for each series fall within the $0.704471-0.707389$ interval for ${ }^{87} \mathrm{Sr} /{ }^{86} \mathrm{Sr}_{\text {. }}$. For ${ }^{143} \mathrm{Nd} /{ }^{144} \mathrm{Nd}$, they fall within $0.512260-0.512508$, excluding the phonolites. The main trend presents a negative correlation in a ${ }^{87} \mathrm{Sr} /{ }^{86} \mathrm{Sr}_{\mathrm{i}}$ vs. ${ }^{143} \mathrm{Nd} /{ }^{144} \mathrm{Nd}_{\mathrm{i}}$ diagram (Fig. 6A).

Phonolites show very high $\mathrm{Rb}$ and low $\mathrm{Sr}$ contents, with very high ${ }^{87} \mathrm{Rb} /{ }^{86} \mathrm{Sr}$ and a wide variation in ${ }^{87} \mathrm{Sr} /{ }^{86} \mathrm{Sr}_{i}$ ratios $(0.705675$ $0.711715)$. Two groups can be defined: one, from ${ }^{87} \mathrm{Sr} /{ }^{86} \mathrm{Sr}_{\text {data, }}$ follows the main series interval (0.705675-0.705983), and the other one shows higher radiogenic values (0.710482-0.711715). In contrast, ${ }^{43} \mathrm{Nd} /{ }^{144} \mathrm{Nd}$ values of phonolites $(0.512377-0.512443)$ fall within the same interval for all series.
A

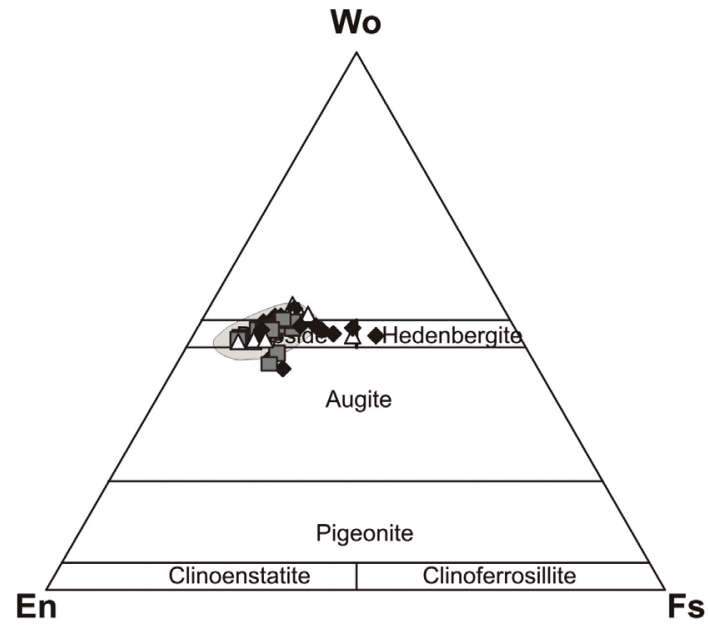

C

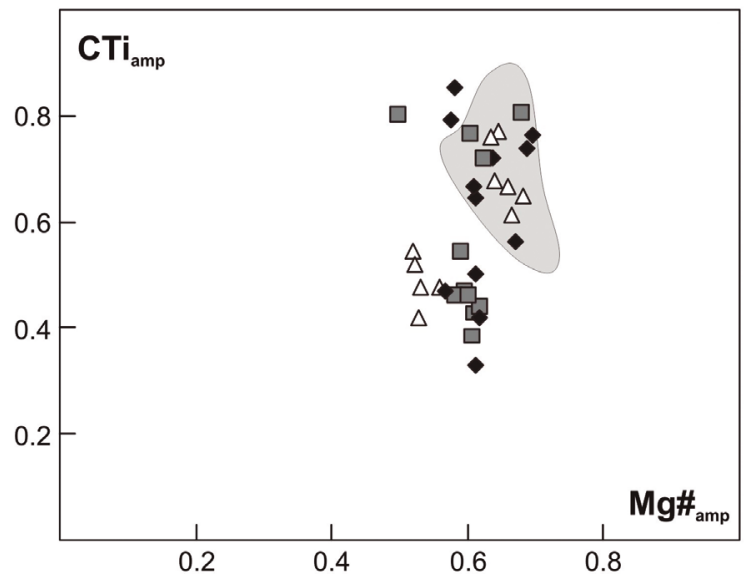

B

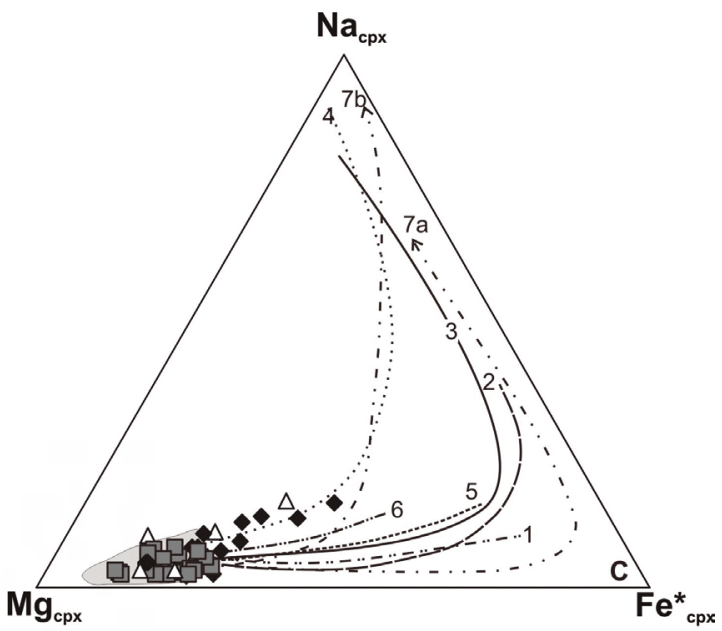

D

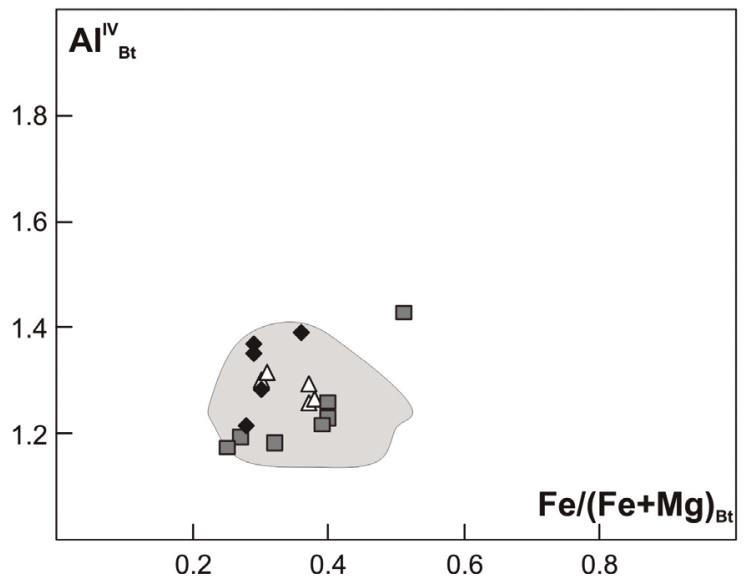

Figure 2. Mineral compositions of weakly to strongly silica-undersaturated alkaline dike series of the Mantiqueira Range. (A) Clinopyroxene compositions in the Wo-En-Fs system (cf. Morimoto et al. 1988). (B) Crystallization trends of clinopyroxenes compared with the main evolutionary trends for clinopyroxenes of alkaline complexes from southeastern Brazil. $\mathrm{Fe}^{*}=\left(\mathrm{Fe}^{2+}+\mathrm{Mn}+\mathrm{Fe}^{3+}-\mathrm{Na}\right)$. References: 1. São Sebastião Island (Bellieni et al. 1990); 2. Vitória Island (Motoki 1986); 3. Monte de Trigo Island (Enrich 2005); 4. Passa Quatro (Brotzu et al. 1992) and Itatiaia (Brotzu et al. 1997); 5. Morro Redondo (Brotzu et al. 1989); 6. Morro de São João (Brotzu et al. 2007); 7(a, b). Búzios Island (Gomes et al. 2017). (C) Amphibole compositions in the Ti of the C-site vs. $\mathrm{Mg} \#{ }_{\text {amp }}\left(\mathrm{Mg}_{\mathrm{T}} /\left(\mathrm{Mg}_{\mathrm{T}}+\mathrm{Fe}_{\mathrm{T}}\right.\right.$, in $\mathrm{apfu}$ ). (D) Biotite compositions on the $\mathrm{Al}^{\mathrm{IV}} \mathrm{vs}$. $\mathrm{Fe} /(\mathrm{Fe}+\mathrm{Mg})(\mathrm{apfu})$ diagram. Symbols: strongly silica-undersaturated series, black diamonds; intermediate series, gray squares; weakly silica-undersaturated series, white triangles. Gray fields are representative of the respective mineral compositions in the Ponte Nova massif (Azzone 2008). 
In general, the most primitive samples of SAS and IS yield the more isotopically primitive values (i.e. lower ${ }^{87} \mathrm{Sr} /{ }^{86} \mathrm{Sr}_{\mathrm{i}}$ and higher ${ }^{143} \mathrm{Nd} /{ }^{144} \mathrm{Nd}$ ) than WAS. However, these intervals are more isotopically evolved than those determined by Thompson et al. (1998) for the least contaminated basic dikes of the area. Exceptions are two samples, one from SAS and one from IS, both lying within a field similar to that of Ponte Nova intrusions, with low degree of contamination (Fig. 6B). Host rocks are also negatively correlated in a ${ }^{87} \mathrm{Sr}^{86} \mathrm{Sr}_{\mathrm{i}}$ vs. ${ }^{143} \mathrm{Nd} /{ }^{144} \mathrm{Nd}_{\mathrm{i}}$ diagram. Their values are more isotopically evolved than those of the alkaline series (Azzone et al. 2016; Fig. 6A).

\section{Ar/Ar ages}

${ }^{40} \mathrm{Ar} /{ }^{39} \mathrm{Ar}$ ages were obtained for three -1.5 -mm-wide biotite macrocrystals from the ST- $04 \mathrm{H}$ tephriphonolite dike. All crystals were analyzed in high-resolution incremental heating experiments, in ten or more steps up to total fusion at $3 \mathrm{~W}$ or $5 \mathrm{~W}$ of laser power. Heating spectra are shown in Figure 7. Corresponding data is presented as supplementary material (Suppl. Tab. A6). Biotite crystals provided very consistent plateau ages of $85.7 \pm 0.7 \mathrm{Ma}$, 85.2 $\pm 0.6 \mathrm{Ma}$ and $84.7 \pm 0.6 \mathrm{Ma}$, all defined by $>90 \%$ of ${ }^{39} \mathrm{Ar}$ released.
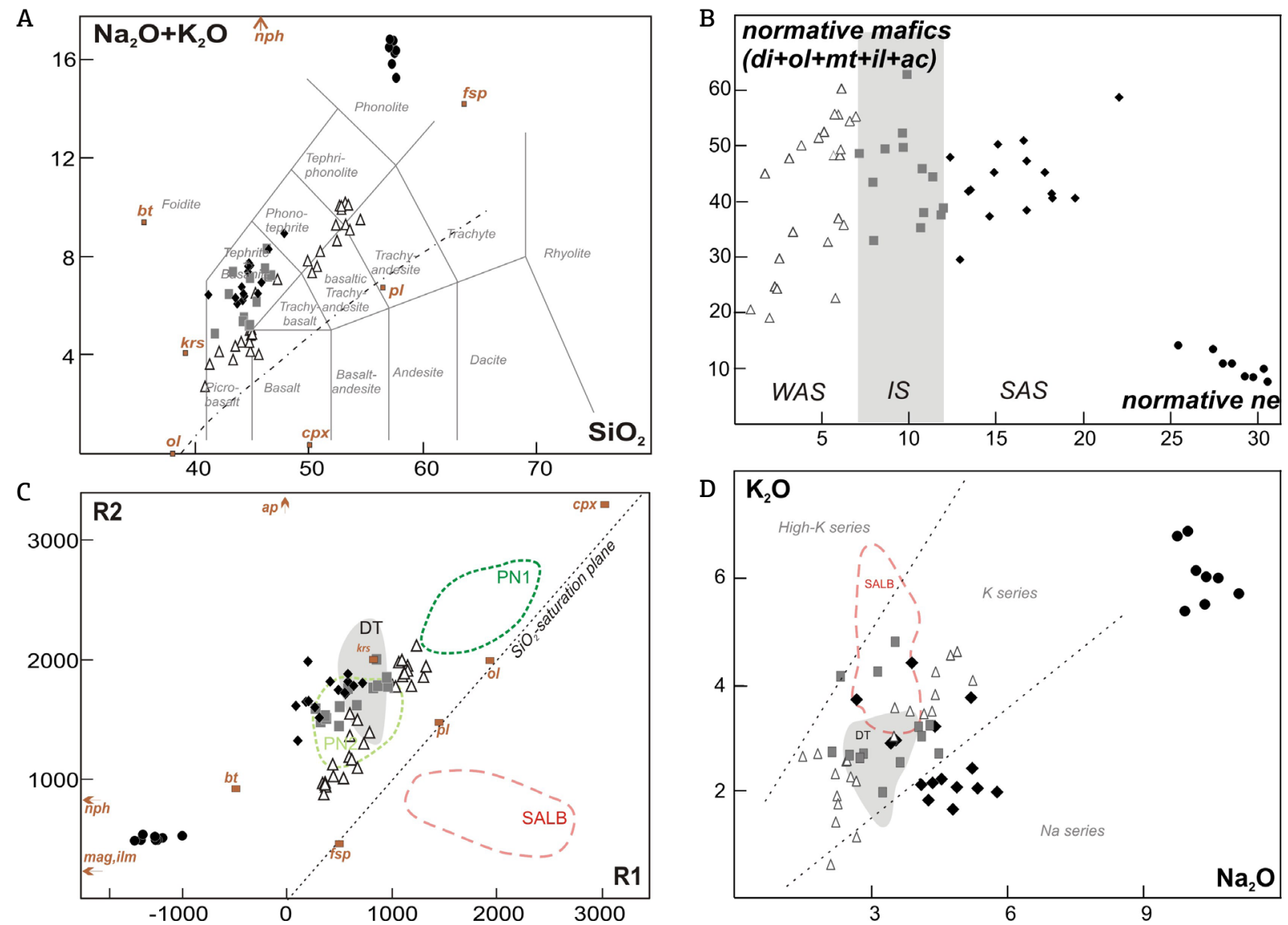

Figure 3. Major-element discrimination diagrams for the weakly to strongly silica-undersaturated alkaline dike series of the Mantiqueira Range. (A) TAS $\left(\mathrm{SiO}_{2}\right.$ vs. $\mathrm{Na}_{2} \mathrm{O}+\mathrm{K}_{2} \mathrm{O}$, in wt\%) diagram (cf. Le Maitre 2002). Dashed line separates alkaline and subalkaline fields (after Irvine \& Baragar 1971). (B) Normative mafics vs. normative nepheline diagram. (C) $\mathrm{R}_{1}-\mathrm{R}_{2}$ diagram (cf. De La Roche et al. 1980). (D) Highly-potassic, potassic and sodic series diagram (after Middlemost 1975). Symbols: strongly-alkaline dike series (SAS), black diamonds; intermediate dike series (IS), gray squares; weakly-alkaline dike series (WAS), white triangles; phonolites, black circles. Average mineral poles compiled from Azzone (2008) are representative of the main assemblage found in the Ponte Nova massif. Abbreviations: ap, apatite; bt, biotite; cpx, clinopyroxene; fsp, feldspar; ilm, ilmenite; krs, kaersutite; mag, magnetite; nph, nepheline; ol, olivine; pl, plagioclase. The DT field is representative of primitive dikes described by Thompson et al. (1998). The SALB field is representative of heterogeneous host rocks of the Serra da Água Limpa batolith (cf. Vinagre et al. 2014a). PN1 and PN2 fields are representative of mafic cumulates and non-cumulatic intrusions from the nearby Ponte Nova massif, respectively (Azzone et al. 2016). 


\section{DISCUSSION}

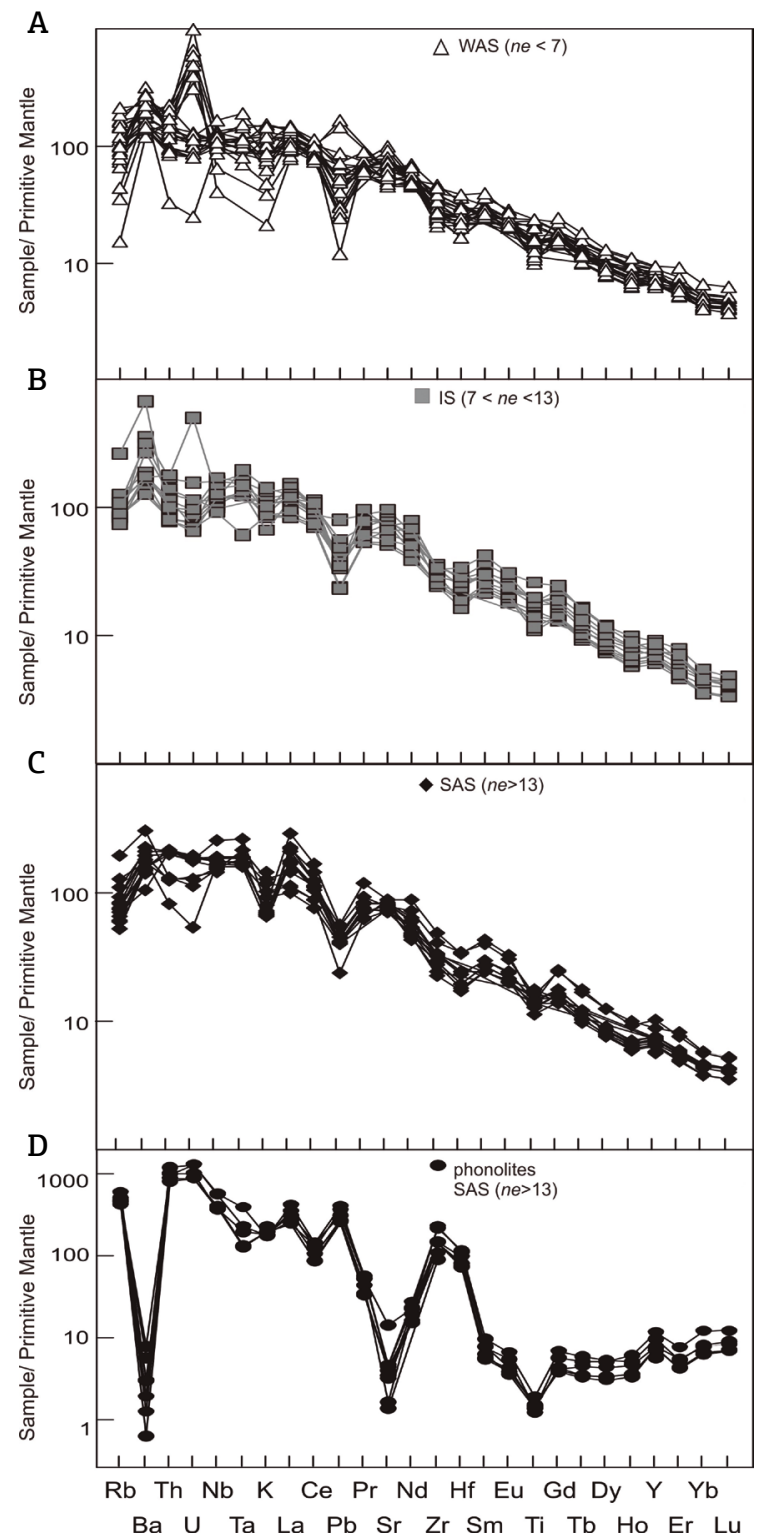

Figure 4. Primitive mantle-normalized (McDonough \& Sun 1995) incompatible element distribution for rocks of the (A) weakly silica-undersaturated series (WAS); (B) intermediate series (IS); (C) strongly silicaundersaturated series (SAS); (D) phonolites of the Mantiqueira Range. Negative anomalies of $\mathrm{K}, \mathrm{Zr}$, Hf, and $\mathrm{Ti}$ are compatible with carbonatites from around the world (Zeng et al. 2010), the feature suggesting melts with contribution from a carbonatedmetasomatized peridotite source. However, negative anomalies of $\mathrm{Pb}$ are typical of alkaline magmas, and such a behavior is affected by extensive contribution of crustal components, as indicated in some occurrences of the weakly silica-undersaturated dike series. Crustal assimilation also seems to be the explanation for the near absence of the negative $\mathrm{K}$ anomaly and positive $U$ anomalies.

\section{Intrusion timing of the alkaline dike series}

Thompson et al. (1998) determined the range of emplacement/crystallization ages of the SMAP magmatic rocks as between approximately 80 and $50 \mathrm{Ma}$. However, new high-quality geochronological data extends the upper limit of that age interval. Sato et al. (2008) presented 84-85 Ma $\mathrm{U}-\mathrm{Pb}$ ages for zircon and baddeleyite concentrates from

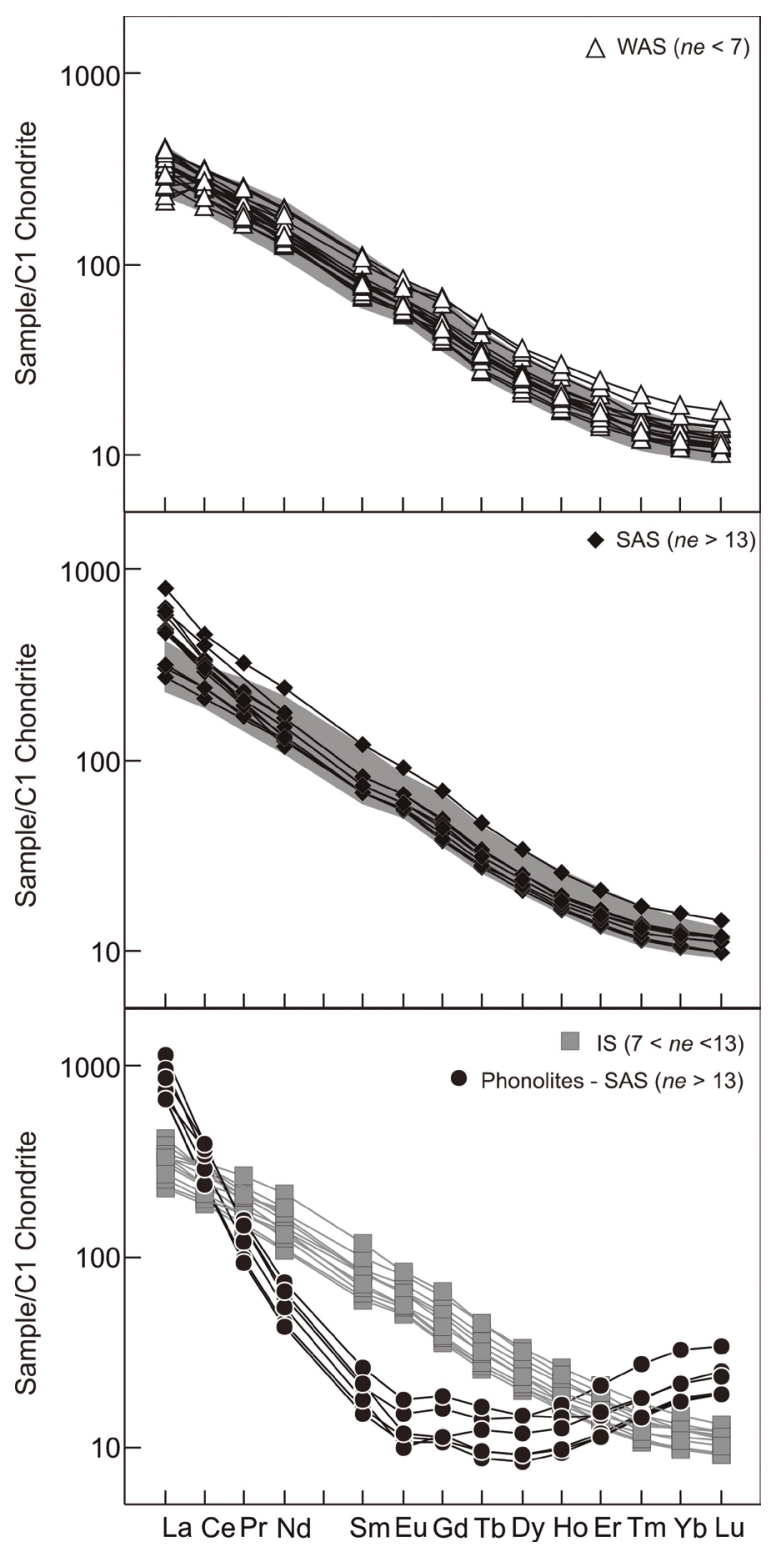

Figure 5. Chondrite-normalized (McDonough \& Sun 1995) REE patterns for rocks of the weakly- to strongly-alkaline dike series of the Mantiqueira Range and nearby host rocks. Gray field is representative of the intermediate dike series. 
São Sebastião island. Enrich et al. (2009), based on Ar-Ar biotite ages, reported an average value of $86.6 \mathrm{Ma}$ for the Monte de Trigo alkaline suite. Azzone et al. (2009) determined an average K-Ar age of 87.6 \pm 1.3 Ma for biotite of the Ponte Nova mafic-ultramafic alkaline massif. For rocks of the Mantiqueira Range, an Ar-Ar result of 80.1 Ma in biotite of a mafic dike from Campos do Jordão was assigned by Regelous (1993), listed in Thompson et al. (1998). New biotite Ar-Ar ages in Supplementary Table 1 and Figure 7 , that average to $85.4 \mathrm{Ma}$, point to the confirmation of the chronogroup $>80 \mathrm{Ma}$ for SMAP inland occurrences. Actually, the alkaline complexes in offshore islands of the State of São Paulo and the Ponte Nova massif were grouped by Riccomini et al. (2005) in a new subprovince
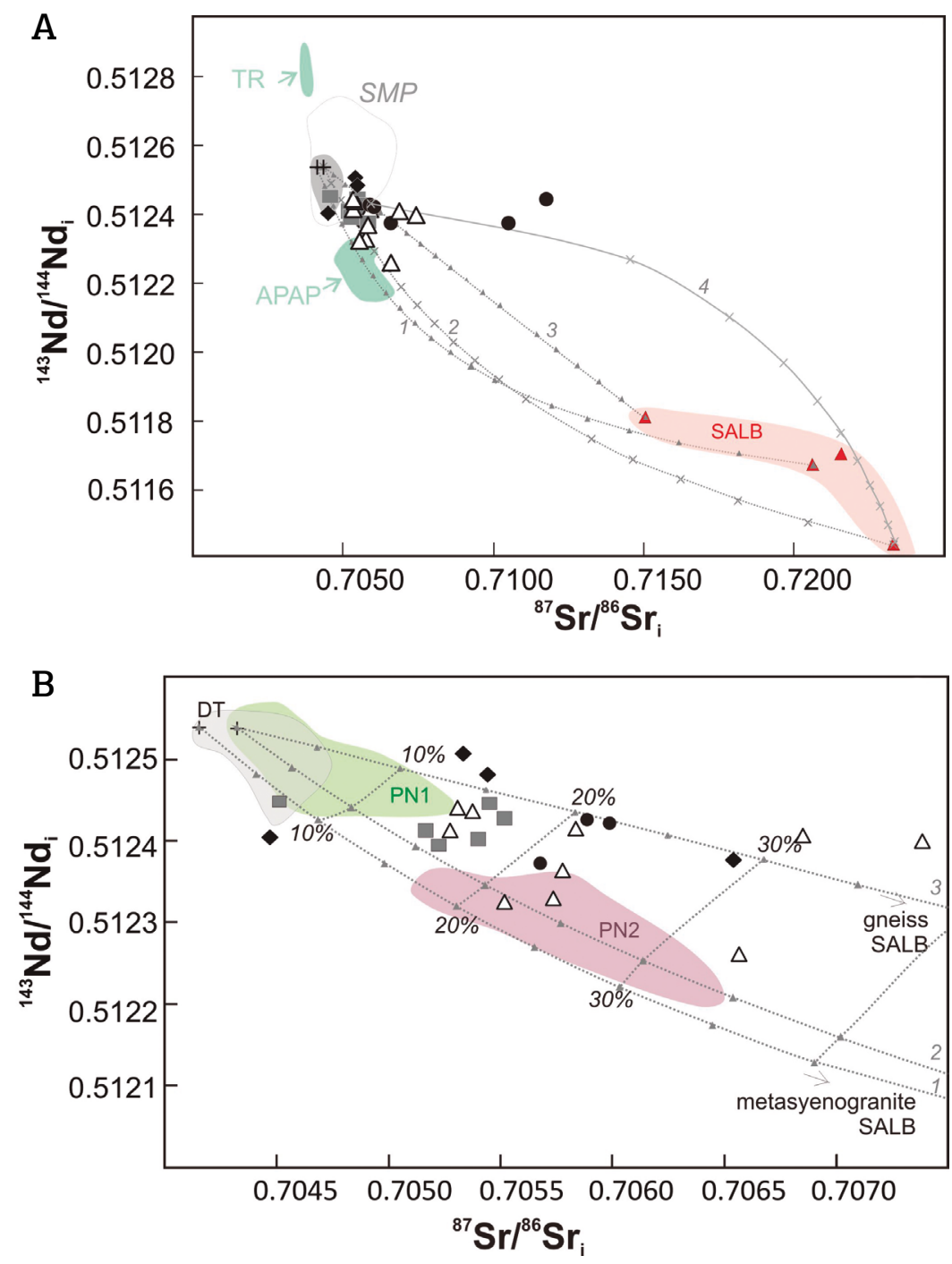

Figure 6. (A) Variation of ${ }^{87} \mathrm{Sr} /{ }^{86} \mathrm{Sr}$ vs. ${ }^{143} \mathrm{Nd} /{ }^{144} \mathrm{Nd}$ for weakly to strongly silica-undersaturated alkaline dike series of the Mantiqueira Range and nearby host rocks. Fields from Trindade Island and Alto Paranaíba Alkaline Province (APAP) compiled from Marques et al. (1999), Gibson et al. (1995) and Araújo et al. (2001). Field for dikes and massifs of the Serra do Mar alkaline province (SMP) compiled from Brotzu et al. (2007) and references therein. Mixing-model curves for the least radiogenic samples representative of the most primitive basic alkaline magmatism of the area (dike from Thompson et al. 1998, and a plug from Azzone et al. 2016; symbols, vertical crosses) to end-members of gneiss and metasyenogranite of the Serra da Água Limpa batholith (curves 1-3, data from Azzone et al. 2016) based on the Albarède (1995) formulae are plotted to evaluate crustal contribution processes (after Azzone et al. 2016). Mixing-model Curve 4 represent a pole of a sample in the Group 1 phonolites (MT-68c) to metasyenogranite end-member, indicating that phonolites could also be affected by crustal contribution. (B) Zoom of (A) diagram. DT field is representative of basic dikes of the Mantiqueira Range as described by Thompson et al. (1998). PN1 and PN2 fields are representative of Ponte Nova intrusions showing lower and higher degrees of crustal contamination, respectively (Azzone et al. 2016). 
that may correspond to an area of Cenozoic uplift adjoining the Santos basin. There, the alkaline magmatism seems to be related to the evolution of the adjoining continental margin, favoring the reactivation of ancient weakness zones, particularly NE-SW-trending parallel Proterozoic shear zones (Ulbrich \& Gomes 1981, Almeida 1983, 1986, Riccomini et al. 2005). This chronogroup is also consistent with new U-Pb perovskite ages determined by Guarino et al. (2013), which define 80-91 Ma for kimberlites and phlogopite picrites and 78-81 Ma for kamafugites of the Alto Paranaíba alkaline province (APAP). It is noteworthy that such age intervals go against the age progression hypothesis
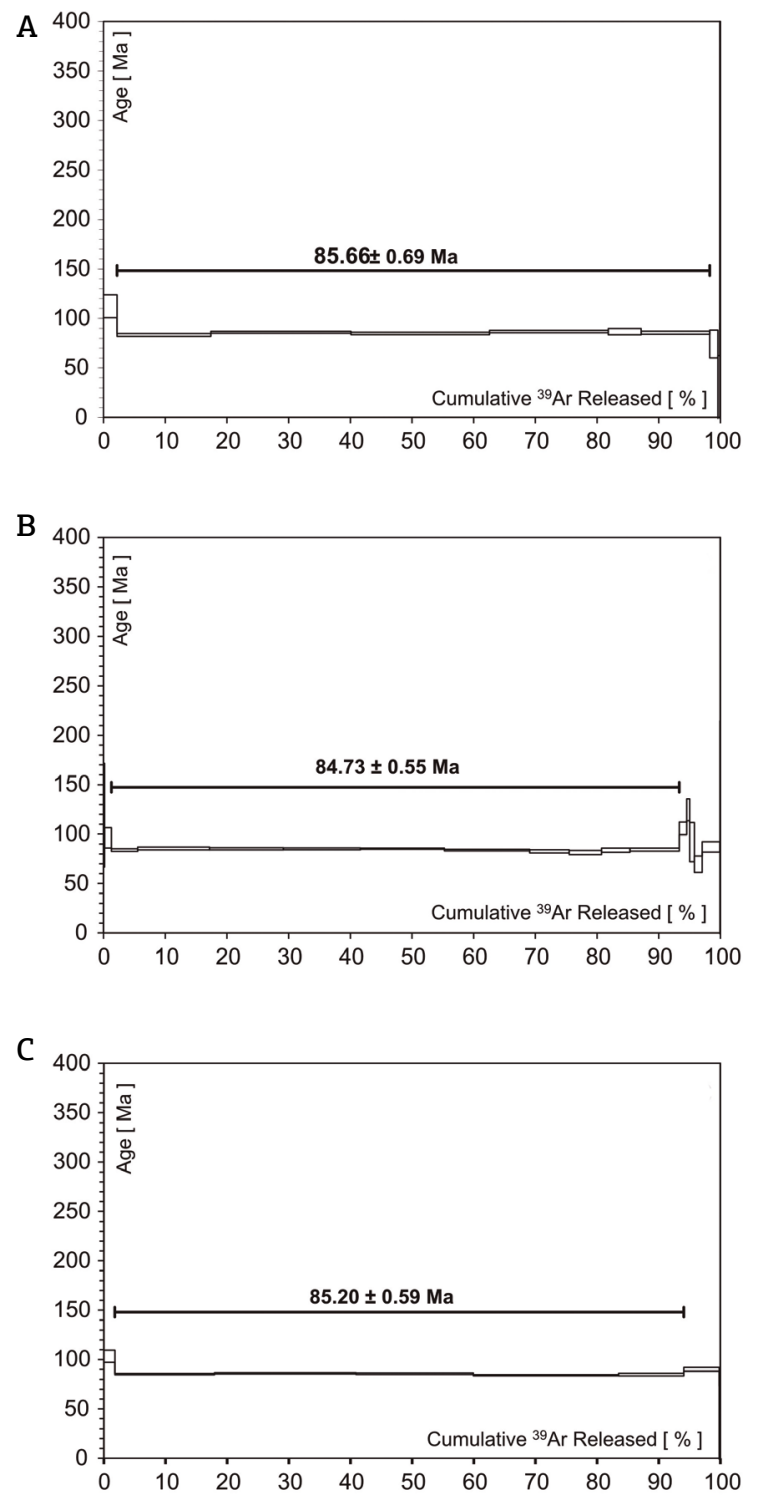

Figure 7. Argon-release age spectra for biotite samples of a tephriphonolite dike (ST-4H) with well-defined plateau ages (WMP). Bars are representative of $2 \sigma$ errors. by Thompson et al. (1998) associated with the ESE track of the Trindade mantle plume.

\section{Fractional crystallization}

The almost similar evolutionary trends observed in the TAS and $\mathrm{R}_{1}-\mathrm{R}_{2}$ diagrams (Figs. 3A and 3C) for the weaklyto strongly-alkaline dike series in the Mantiqueira Range) seem controlled mainly by fractional crystallization (Figs. 3A and 3C). Previous thermodynamic crystallization models achieved through the MELTS algorithm using primitive regional basanite dikes (Menezes et al. 2015, Azzone et al. 2016) are in accordance with the petrographic descriptions. They indicate that the early-crystallized phases are olivine, spinel, and clinopyroxene, whereas apatite and plagioclase represent late fractioning phases. The evolutionary trends of these melts point to a progressive reduction of $\mathrm{MgO}$, $\mathrm{TiO}_{2}$ and $\mathrm{CaO}$ and, subordinately, an increase in $\mathrm{SiO}_{2}$, $\mathrm{Al}_{2} \mathrm{O}_{3}$ and alkalis (Suppl. Tabs. A2-A5). These trends also show that basanite melts could have evolved mainly from fractional crystallization, reaching tephrite-phonolite and even more extreme phonolite compositions, as observed in the Búzios Island rocks, for example (Gomes et al. 2017). In fact, based on geochemical compositions, the parental magma of all three alkaline dike series could potentially evolve to phonolite compositions from fractional crystallization of a gabbroic cumulate assemblage. However, the high degree of $\mathrm{SiO}_{2}$-undersaturation of these magmas seems to link the phonolites with the SAS series. However, a compositional gap in this series is found between 50 and $60 \mathrm{wt} \% \mathrm{SiO}_{2}$ (Figs. 3A and 3B), an interval also referred in literature as the "Daly gap". This gap can be interpreted as a consequence of the viscosity increase in middle evolution steps that would prevent migration of intermediate magma to deep crustal levels (e.g., Thompson et al. 2001). However, although fractional crystallization accounts for the continuous part of the series, other scenarios could be envisaged for the origin of the phonolites and of the SAS compositional gap. For example, partial melting of basanite rocks (like those of SAS) or even of alkaline gabbroic cumulates possibly emplaced at deeper crustal levels could also produce phonolite magmas with similar isotopic ratios, as found by Legendre et al. (2005) in the Ua Pou Island, French Polynesia, and by Avanzinelli et al. (2004) in the Pantelleria volcano, Italy.

At the primitive extreme of each series, the petrographic and whole-rock geochemical data indicates that the lamprophyre samples (basanite and tephrite compositions) are representative of the combination of a magmatic liquid with accumulation of crystals, as already shown by Menezes et al. (2015). This is also evidenced by the behavior of trace elements, in which higher $\mathrm{Cr}, \mathrm{Ni}$ and $\mathrm{Co}$ and 
lower $\mathrm{Sr}$ and $\mathrm{Ba}$ concentrations of the primitive magmas of each series (Suppl. Tabs. A2-A5) are positively correlated with a higher crystal cargo of the samples. The porphyritic character of the most primitive dikes of each series (with predominance of olivine and clinopyroxene macrocrysts) indicates a complex plumbing system prior to the final stage of emplacement at shallow crustal levels. Mega- and macrocryst populations with typical disequilibrium features are mainly referred to as antecrysts (Menezes et al. 2015), similarly to those studied by Azzone et al. (2016) in Ponte Nova occurrences. These antecryst populations could be representative of crystallization stages in a chamber environment, at lower levels in the same magmatic system. At the evolved extreme, the upward concave-shape pattern of the REE of the peralkaline phonolites, with high depletion of intermediate-REE (Fig. 5), is a worldwide feature of evolved phonolite magmas, typically associated with previous fractionation of titanite (e.g., Berger et al. 2014, Baudoin \& Parat 2015, Melluso et al. 2017) in some intermediary stage. Although not found in primitive samples of the series, titanite is a typical accessory mineral in the miaskitic nepheline syenite and syenite massifs of the SMAP (e.g., Bellieni et al. 1990, Brotzu et al. 1992, 1997 , 2007, Ulbrich et al. 2005, Gomes et al. 2017, Enrich et al. 2009, Rosa \& Ruberti 2017, Melluso et al. 2017), from which peralkaline magmas could have derived.

\section{Assimilation and crustal contribution processes}

Low level of assimilation of fusible crustal rock-types by heterogeneous mantle-derived melts of the Serra do Mar province was previously mentioned by Thompson et al. (1998) and Brotzu et al. (2005, 2007). Azzone et al. (2016) showed the importance of crustal contamination even for alkaline basic magmas, postulating that they can occur at both low and high depths under turbulent emplacement flow conditions. Based on thermodynamic models developed through the MELTS algorithm, these authors proposed that parental (or primitive and high-T) alkaline basic magmas can be strongly affected by high levels of contamination subsequently to their initial stages of crystallization, when there is enough energy to assimilate partial melts of crustal host rocks. In the Ponte Nova massif, for example, assimilation contributed to the wide ${ }^{87} \mathrm{Sr} /{ }^{86} \mathrm{Sr}$ and ${ }^{143} \mathrm{Nd} /{ }^{144} \mathrm{Nd}$ ranges and for the increased $\mathrm{K}_{2} \mathrm{O} / \mathrm{Na}_{2} \mathrm{O}, \mathrm{Ba} / \mathrm{Sr}$ and $\mathrm{Rb} / \mathrm{Sr}$ signatures (Azzone et al. 2016). These enrichment levels were related to the important role of biotite breakdown in the assimilation of partially melted hosts. The authors also suggested that similar assimilation could be an important component of the potassic character of basic alkaline dikes in the Serra do Mar province, although the mixing of heterogeneous mantle-enriched sources might have played a predominant role.

That could be the case for the three alkaline series proposed here for the Mantiqueira Range. Reiners et al. (1995) and Tegner et al. (2005) indicated that larger degrees of felsic crust assimilation by basic mantle-derived magmas are expected in early crystallization stages (with the ratio of crustal assimilated mass to crystallized mass, the $r$ factor, greater than a unit) due to the heat and mass transfer dependencies of the AFC processes. Hence, to better quantify crustal assimilation, mixing curves are considered more appropriated than common AFC curves with a fixed $r$ during all crystallization stages. Differences in the proportions of mantle-crust components between WAS and SAS were estimated using mixing-model isotope curves (Fig. 6). The mixing-model curves for initial ${ }^{87} \mathrm{Sr} /{ }^{86} \mathrm{Sr}$ and ${ }^{143} \mathrm{Nd} /{ }^{144} \mathrm{Nd}$ ratios follow ratio-ratio relationships in binary mixing (Albarède 1995). For these models, two possibly pristine parental magma signatures were assumed for the least isotopically evolved samples from the Mantiqueira Range: one representing the mafic dikes (Thompson et al. 1998), the other one representing a small inner plug in the Ponte Nova massif (Azzone et al. 2016). The chosen crustal poles are representative of biotite gneiss and metasyenogranite of the Serra da Água Limpa batholith (Azzone et al. 2016). Samples of the three series are plotted in the range of the mixing lines (Fig. 6B), suggesting initial mixing between enriched-mantle parental melts (with lower ${ }^{87} \mathrm{Sr} /{ }^{86} \mathrm{Sr}$ and higher ${ }^{143} \mathrm{Nd} /{ }^{144} \mathrm{Nd}$ ratios) and partially melted hosts (having higher ${ }^{87} \mathrm{Sr} /{ }^{86} \mathrm{Sr}$ lower ${ }^{143} \mathrm{Nd} /{ }^{144} \mathrm{Nd}$ ratios), analogous to the scenario proposed for the nearby Ponte Nova massif by Azzone et al. (2016). An initial process, with high-T mantle-magma still dominated by the liquid phase mix and different degrees of partial melts of heterogeneous crustal rocks, could account for the isotopic differences between the least isotopically evolved samples of each series. In general terms, SAS seems less affected by crustal contamination than WAS (Fig. 6B). Geochemical signatures point to crustal contamination, and are in agreement with the isotopic data. SAS presents negative anomalies of $\mathrm{K}$ and $\mathrm{Pb}$ in the primitive-mantle spidergrams (Fig. 4C), high $\mathrm{Ce} / \mathrm{Pb}$ (Figs. $8 \mathrm{~A}$ and $8 \mathrm{~B}$ ) ratios, low $\mathrm{K}_{2} \mathrm{O} / \mathrm{Na}_{2} \mathrm{O}$ (Fig. 3D) and Rb/Sr (Figs. $8 \mathrm{~A}$ and $8 \mathrm{C}$ ), whereas WAS presents a decreasing trend in $\mathrm{Ce} / \mathrm{Pb}$ ratios (Fig. 8A) and a progressive enrichment in $\mathrm{K}$ (Fig. 3A) and $\mathrm{Pb}$ levels, $\mathrm{Rb} / \mathrm{Sr}$ and $\mathrm{Ba} / \mathrm{Sr}$ ratios (Fig. $8 \mathrm{C}$ ), and higher $\mathrm{K}_{2} \mathrm{O} / \mathrm{Na}_{2} \mathrm{O}$ (Fig. 3D). Ce/Pb ratios also present a positive correlation with ${ }^{143} \mathrm{Nd} /{ }^{144} \mathrm{Nd}$ ratios (Fig. 8B).

It should be noticed that, due to lower T-gradients between magma and host rocks, high levels of contamination are expected at deeper crustal levels (Reiners et al. 1995, Tegner et al. 2005). Therefore, alkaline mantle-derived 
melts could have also assimilated crustal material within a magmatic plumbing system at deeper levels before its final emplacement at upper crust levels. The macrocryst population and their reaction textures indicate that these magmas underwent some lower-level chamber stages, better conditions being then set for assimilation.

As for phonolites, the group which presents higher ${ }^{87} \mathrm{Sr} /{ }^{86} \mathrm{Sr}$ ratios and similar ${ }^{143} \mathrm{Nd} /{ }^{144} \mathrm{Nd}$ for the main trend can also be explained by crustal assimilation from phonolite initial compositions. Mixing-model curves were also drawn to evaluate this group (Curve 4 in Fig. 6A). In this case, initial compositions were assigned to a phonolite sample (MT-68C) that follows the main isotopic trend, with chosen crustal poles representing Serra da Água Limpa batholith metasyenogranite (Azzone et al. 2016). Differently from the first ones, owing to the high
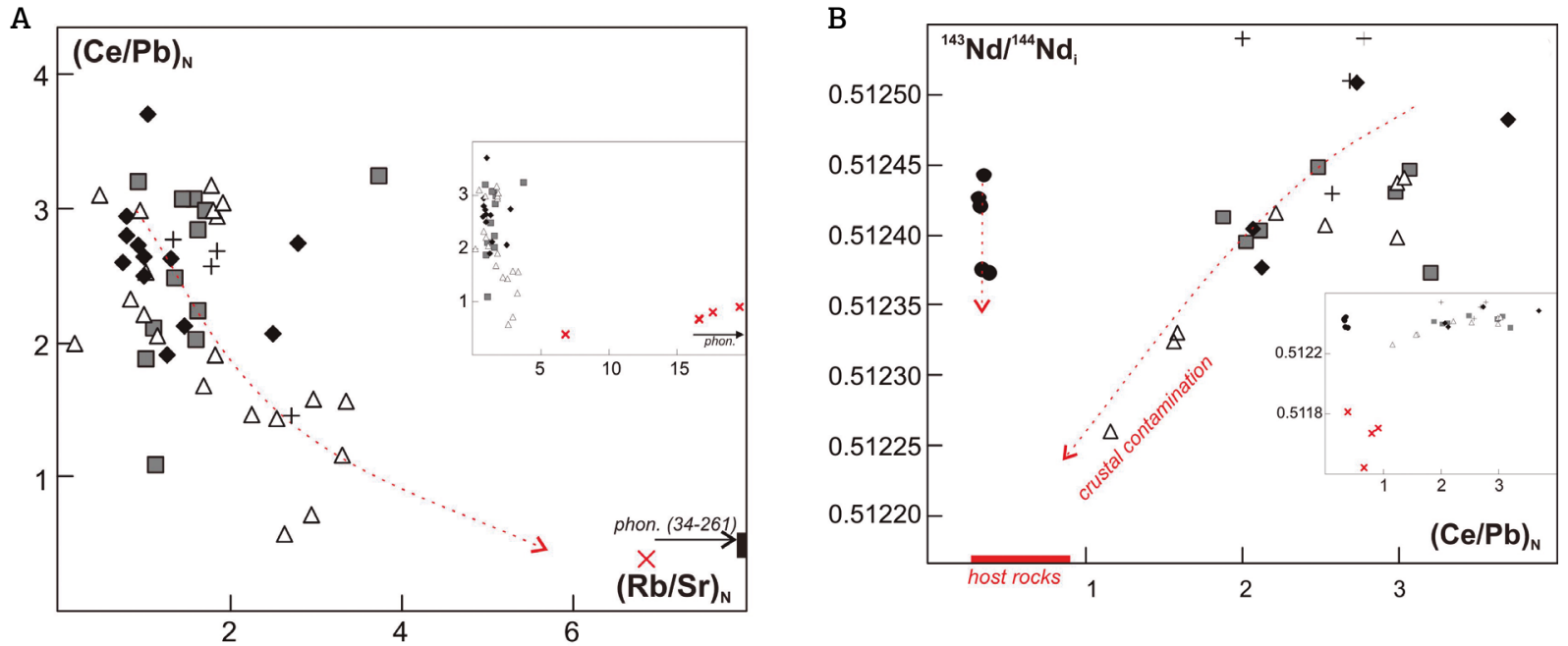

C

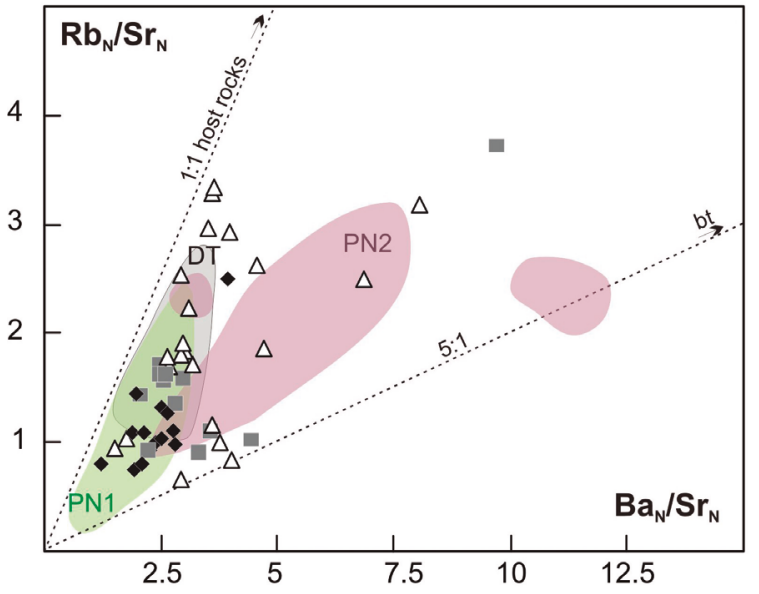

D

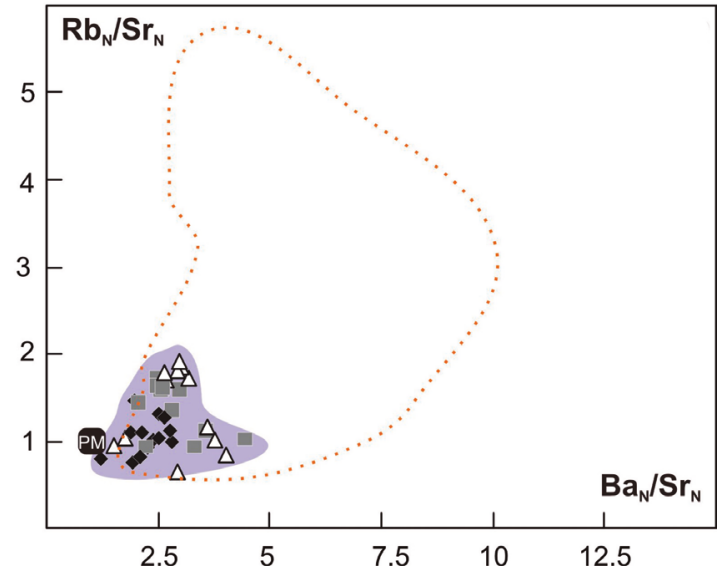

Figure 8. Primitive mantle-normalized (McDonough \& Sun 1995) trace element ratios for the weakly to strongly silica-undersaturated alkaline dike series of the Mantiqueira Range and nearby host rocks. $(\mathrm{A})(\mathrm{Rb} / \mathrm{Sr})_{\mathrm{N}} \mathrm{vs} .(\mathrm{Ce} / \mathrm{Pb})_{\mathrm{N}}$ diagram. The inset presents the entire range of $(\mathrm{Rb} / \mathrm{Sr})_{\mathrm{N}}$ obtained for host rocks. $(\mathrm{B})(\mathrm{Ce} / \mathrm{Pb})_{\mathrm{N}} \mathrm{vs} .{ }^{143} \mathrm{Nd}^{144} \mathrm{Nd} \mathrm{i}_{\mathrm{i}}$ diagram. The inset presents the entire range of $(\mathrm{Ce} / \mathrm{Pb})_{\mathrm{N}}$ obtained for host rocks. Possible trends of crustal contribution processes are indicated by the dashed lines. $(\mathrm{C})(\mathrm{Ba} / \mathrm{Sr})_{\mathrm{N}} \mathrm{vs}$. $(\mathrm{Rb} / \mathrm{Sr})_{\mathrm{N}}$ diagram. Fields for low-contaminated (PN1) and highly-contaminated intrusions of the Ponte Nova massif (PN2) are shown for comparison. Host rock data and biotite compositional controls from Azzone et al. (2016). High levels of $\mathrm{Ce} / \mathrm{Pb}$ for low levels of $\mathrm{Rb} / \mathrm{Sr} \mathrm{and} \mathrm{Ba} /$ $\mathrm{Sr}$ are compatible with alkaline mantle-derived melts (Orejana et al. 2008), whereas high levels of $\mathrm{Rb} / \mathrm{Sr}$ and $\mathrm{Ba}$ / $\mathrm{Sr}$ for low levels of $\mathrm{Ce} / \mathrm{Pb}$ are typical of the contribution from partial melts of crustal basement rocks. (C) Same as (B), but plotting only low-degree contaminated dikes from each alkaline series, compared with fertile source ideal composition (primitive mantle values, $\mathrm{PM}$ ) and with the field for kamafugite/kimberlite compositions of the Alto Paranaíba province. All values of $\mathrm{Rb} / \mathrm{Sr}$ and $\mathrm{Ba} / \mathrm{Sr}$ are higher than $\mathrm{PM}$, suggesting a metasomatized mantle source, and within the field for kamafugite/kimberlite compositions. 
$\mathrm{Rb} / \mathrm{Sr}$ ratios found for the phonolites, the mixing curve presents a convex-like shape. Contaminated phonolites, by these models, present lower levels of crustal contribution at this stage. Geological evidence also supports possible crustal contamination for some phonolites. The rounded xenoliths of syenogranites with diffusion rings in the phonolite aphanitic matrix attest to this process, at least at a local scale. Due to the extremely evolved compositions of these peralkaline phonolites, trace element ratios were not too sensitive to crustal contamination, differently from the more primitive samples of each series as indicated above.

Crustal contribution played an important role in the differentiation trend of SAS, IS and, especially, WAS. However, it seems that the initial assimilation process could not be the sole responsible for the generation of WAS parental magmas from SAS parental ones, once the least radiogenic samples of each series present similar ${ }^{87} \mathrm{Sr} /{ }^{86} \mathrm{Sr}$ and ${ }^{143} \mathrm{Nd} /{ }^{144} \mathrm{Nd}$ ratios with the same trace-element anomalies, but with different normative nepheline values (Fig. 3D). Therefore, other parameters need to be considered to discriminate both series, such as mantle heterogeneities.

\section{Mantle source heterogeneities and the role of carbonate-rich metasomatism}

Thompson et al. (1998) and Brotzu et al. (2005, 2007), based on isotopic and geochemical signatures of less contaminated samples of the Serra do Mar alkaline province, proposed a heterogeneous mantle source for the genesis of potassic magmas. Thompson et al. (1998) assigned the geochemical and isotopic signatures of these magmas to manthe sources representative of a mixture between an OIBcomponent (similar to the composition of Trindade volcanic island) and a subcontinental lithospheric mantle component that resembled Alto Paranaíba kamafugitic rocks. In their petrological model, the source of the OIB-component is attributed to a convective mantle which, during its uprise, was mixed in variable degrees with different melts from fusible metasomites within the sublithospheric mantle. Brotzu et al. $(2005,2007)$, in turn, interpreted the same signatures as a result of low partial melting of a shallow-level continental lithospheric mantle source subject to varying degrees of metasomatism, such as a phlogopite-bearing spinel-lherzolite with minor amounts of titanite and apatite. In this scenario, kamafugite and kimberlite melts similar to those of the Alto Paranaíba province are thought to have been metasomatic agents in the lithospheric mantle. Similarly, Guarino et al. (2013) attributed the origin of the potassic, ultrapotassic and carbonatitic rocks of the Alto Paranaíba province to a source assemblage made up of metasomatized mica-carbonate garnet lherzolite.
Neither Thompson et al. (1998) nor Brotzu et al. (2005, 2007) reported the occurrence of strongly silica-undersaturated dike series of sodic nature in the Mantiqueira Range or the entire the Serra do Mar province, which is considered to be of potassic affinity. However, potassic and sodic alkaline series in close temporal and spatial association is a typical feature of Lages and Eastern Paraguay occurrences, which are also related to the meso-cenozoic alkaline magmatism of the South American Platform (Traversa et al. 1996, CominChiaramonti et al. 1997, Gibson et al. 1999, 2006). For such situations, a phlogopite-bearing carbonate-metasomatized peridotite source was proposed by Comin-Chiaramonti et al. (1997) and Gibson et al. (2006).

Considering these hypotheses, a possible scenario for the generation of the SAS, IS and WAS series in the Mantiqueira Range could involve vein-plus-wall-rock melting (Foley 1992). In such cases, variations in the degree of alkalinity and of incompatible element (IE) enrichment would also be associated to the participation of modified signatures of the mantle wall-rock, their modal variation (e.g., cpx/gt ratios in a peridotite source), and the composition and melting degree of metasomatic veins. A potassic component of the mantle source, attributed to veins of ultrapotassic melts similar to those of the APAP (Thompson et al. 1998, Brotzu et al. 2005, 2007), could be inferred by trace element ratios and by isotopic signatures. In a $(\mathrm{Rb} / \mathrm{Sr})_{\mathrm{N}} \mathrm{vs}$. $(\mathrm{Ba} / \mathrm{Sr})_{\mathrm{N}}$ diagram (Fig. 8C), SAS, IS and WAS least-contaminated primitive samples exhibit an intermediate composition between an enriched mantle component (PM, McDonough \& Sun 1995) and Brazilian kamafugites, phlogopite picrites and kimberlites (KM, Comin-Chiaramonti \& Gomes 2005, Brod et al. 2005, Guarino et al. 2013). In the diagram, SAS has a more restricted composition than IS and WAS, showing lower $\mathrm{Rb} / \mathrm{Sr}$ and $\mathrm{Ba} / \mathrm{Sr}$ signatures. In a ${ }^{87} \mathrm{Sr} /{ }^{86} \mathrm{Sr}$ vs. $\mathrm{Nd} / \mathrm{Nd}$ diagram (Fig. 6), the SMAP primitive magmas (including those of the Mantiqueira Range), present an intermediate isotopic composition in a mixing-line, having one pole with a signature similar to that of Trindade sodic melts and one pole of average ultrapotassic kamafugites and kimberlites of the APAP (Thompson et al. 1998, Brotzu et al. 2007). Also, high levels of $\mathrm{La}_{\mathrm{N}} / \mathrm{K}_{\mathrm{N}}$ ratio (> 1) are owed to residual phlogopite in the source (Gibson et al. 1999). For the $\mathrm{La}_{\mathrm{N}} / \mathrm{K}_{\mathrm{N}}$ ratio, WAS and IS display values between 1.0 and 2.0, most around 1.0, whereas SAS values are higher than 2.3 (Suppl. Tabs. A2-A5). These restricted $\mathrm{Rb} / \mathrm{Sr}$ and $\mathrm{Ba} / \mathrm{Sr}$ levels and the high $\mathrm{La} / \mathrm{K}$ values indicate that phlogopite acted as a residual mineral in the genesis of SAS.

In fact, SAS presents well-defined $\mathrm{K}$-, $\mathrm{Zr}$-, $\mathrm{Hf}$ - and Ti-negative anomalies in a primitive mantle-normalized spidergram (Fig. 4C). The same behavior is noticed for carbonatites worldwide (Zeng et al. 2010), which suggests a 
greater contribution of carbonate-veins in the mantle to its generation. Azzone et al. (2013), Menezes et al. (2015) and Chmyz et al. (2017) attributed a $\mathrm{CO}_{2}$-rich metasomatized mantle source to different basanitic compositions in equilibrium with cumulates of the Juquiá and Jacupiranga alkaline-carbonatitic complexes, as well as lamprophyric dikes of the Ponta Grossa arch. Chemically, a $\mathrm{CO}_{2}$-rich mantle metasomatism can increase $\mathrm{CaO} / \mathrm{Al}_{2} \mathrm{O}_{3}, \mathrm{La} / \mathrm{Zr}, \mathrm{Zr} / \mathrm{Hf}$ and decrease $\mathrm{Ti} / \mathrm{Eu}$ ratios in the source and, consequently, in partial melts (Yaxley et al. 1991, 1998, Rudnick et al. 1993, Green et al. 2004, Azzone et al. 2013). Mineralogically, the action of carbonate-rich melts and fluids in a peridotitic upper mantle reduces the amount of orthopyroxene, increases the concentration of clinopyroxene, and accounts for the presence of wehrlite assemblages (Green \& Wallace 1988, Yaxley et al. 1991, Rudnick et al. 1993, Moore \&

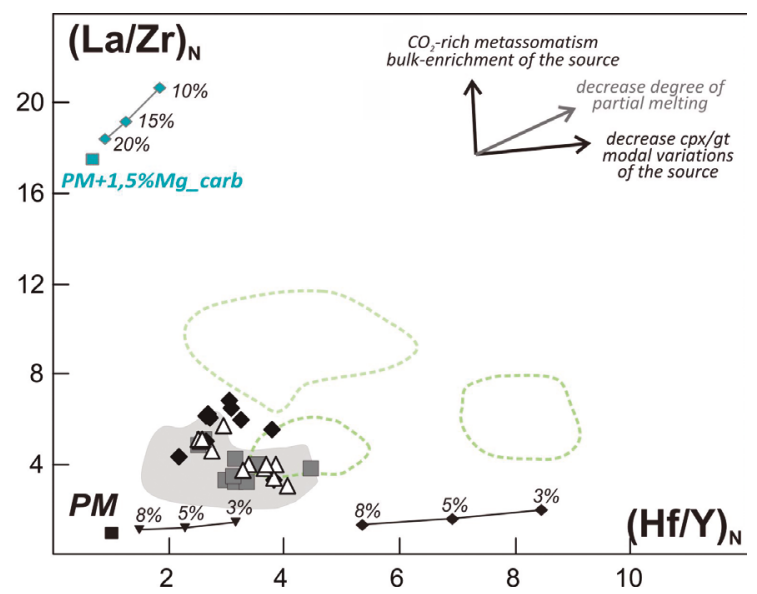

Figure 9. $(\mathrm{Hf} / \mathrm{Y})_{\mathrm{N}}$ vs. $(\mathrm{La} / \mathrm{Zr})_{\mathrm{N}}$ (primitive mantlenormalized; McDonough \& Sun 1995) for the most primitive samples of the weakly- to strongly silicaundersaturated alkaline dike series of the Mantiqueira Range. Non-modal batch melting models for different mantle sources are also shown (complemented from Azzone et al. 2013). Partition coefficients from Green et al. (2000), Adam \& Green (2003), and Zanetti et al. (2004). Trace element compositions of the metasomatic veins (blue square) based on primitive mantle (McDonough \& Sun 1995) plus $1.5 \mathrm{wt} \%$ of a mantle Mg-carbonatite (Hoernle et al. 2002). Trace element compositions of wall-rock (black square) based on primitive mantle composition (McDonough \& Sun 1995). Modal compositions of mantle source residua: inverted triangles, off-craton garnet lherzolite; black diamonds, primitive mantle garnet lherzolite; blue diamonds, theoretical wehrlite. Italic numbers indicate the degree of partial melting. Gray field represents Serra do Mar province primitive dikes (Brotzu et al. 2007 and references therein). Dashed fields: composition of calculated primitive melts and dikes from Ponta Grossa arch occurrences (Azzone et al. 2013, Menezes et al. 2015, Chmyz et al. 2017).
Wood 1998, Dalton \& Wood 1993). The alkaline series of the Mantiqueira Range show $\mathrm{CaO} / \mathrm{Al}_{2} \mathrm{O}_{3}$ ratios (0.53-1.21), similar to experimental data for a carbonated pyroxene-rich source (0.6-0.7; Hirschmann et al. 2003) and a carbonated peridotite source (1.0-11.0; Dasgupta et al. 2007), and ratios similar to lamprophyre dikes associated with the Juquiá and Jacupiranga complexes (0.74-1.72; Beccaluva et al. 1992, Gibson et al. 1999, Menezes et al. 2015, Chmyz et al. 2017). Also, they show higher La/Zr (3.2-6.8) and Zr/Hf (1.0-1.6) and lower $\mathrm{Ti} / \mathrm{Eu}$ ratios than primitive mantle values $\left(\mathrm{Ti}_{\mathrm{N}} /\right.$ $\mathrm{Eu}_{\mathrm{N}}$ 0.43-0.85). SAS presents higher $\mathrm{La} / \mathrm{Zr}$ and $\mathrm{Zr} / \mathrm{Hf}$ values than IS and WAS.

Non-modal batch melting models for trace elements by Azzone et al. (2013) were adapted to evaluate the contribution of $\mathrm{CO}_{2}$-rich metasomatic fluids and/or melts (producing a clinopyroxene-veined network structure) in the hypothesis of a vein-plus-wall-rock mechanism for SAS, IS and WAS (Fig. 9). A comparison between the alkaline series indicate that they derive from different degrees of $\mathrm{CO}_{2}$-rich metasomatism, SAS showing higher contribution of carbonated pyroxene-rich veins than IS, WAS and most alkaline dikes of the Serra do Mar province (Fig. 9). SAS, on the other hand, presents similar ranges of $\mathrm{La}_{\mathrm{N}} / \mathrm{Zr}_{\mathrm{N}}$ ratios than lamprophyre dikes near the Juquiá and Jacupiranga complexes, for which a carbonated pyroxene-rich source is attributed (Azzone et al. 2013, Chmyz et al. 2017). The composition of SAS is also similar to that of the intra-plate alkaline basalts of Shandong (China), from which Zeng et al. (2010) evidenced the same carbonatitic fingerprints as in the mantle source.

The alkaline series of the present study have a similar range of $\mathrm{Hf}_{\mathrm{N}} / \mathrm{Y}_{\mathrm{N}}$ ratios plotted within the Serra do Mar province dikes field (Fig. 9). The wide variation of $\mathrm{Hf}_{\mathrm{N}} / \mathrm{Y}_{\mathrm{N}}$ ratios suggests either a variable degree of partial melting or a garnet peridotite source with different cpx/gt proportions (Azzone et al. 2013, Chmyz et al. 2017). In the case of dikes, modal variations in the modal source seem more plausible. In fact, according to Stracke (2012), small-scale heterogeneities (i.e. kilometer scale) in melting portions of mantle sources are expected to occur due to crust-mantle recycling.

As emphasized by Ruberti et al. (2012), the origin of mantle metasomatism events in the southeastern South American Platform can be attributed to infiltration of fluids or melts related to subduction-driven processes involved in the agglutination of Gondwana in the Neoproterozoic (Heilbron \& Machado 2003), or to small-degree melting of astenospheric mantle fractions in a distensive environment related to the breakup of that supercontinent in the Mesozoic (Almeida 1983, CominChiaramonti \& Gomes 2005). Regardless of the metasomatism events that affected the lithospheric mantle, the hypothetical scenario for the Mantiqueira Range points 
to a phlogopite-bearing carbonated-metasomatized peridotite in the Upper Cretaceous. The sodic nature of the strongly alkaline series appears to represent a greater contribution of carbonated pyroxene-rich veins in a heterogeneous mantle source.

\section{CONCLUSIONS}

In a restricted area of the SMAP in the Mantiqueira Range, three series of alkaline dikes were characterized: a strongly silica-undersaturated series (normative ne $>13$ ), of sodic character, represented by basanites, tephrites, phonotephrites and phonolites; an intermediate series ( 7 > normative ne $>13)$, of potassic character, with only basanites and tephrites; and a weakly alkaline series (normative ne $<7$ ), of potassic character, consisting mostly of basanite, tephrites, alkali basalts, basaltic trachyandesites, phonotephrites, tephriphonolites and trachyandesites. Similar evolution trends controlled mainly by early fractionation of olivine, spinel and clinopyroxene, followed by plagioclase and apatite fractionation are indicated for these series.

The three series exhibit different degrees of crustal assimilation, which contributed to the wide variation in ${ }^{87} \mathrm{Sr} /{ }^{86} \mathrm{Sr}_{\mathrm{i}}$ and ${ }^{143} \mathrm{Nd} /{ }^{144} \mathrm{Nd}_{\mathrm{i}}$ isotopic ratios, the increased $\mathrm{K} 2 \mathrm{O} / \mathrm{Na}_{2} \mathrm{O}$ and $\mathrm{Ba} / \mathrm{Sr}$ and $\mathrm{Rb} / \mathrm{Sr}$ ratios and the decreased $\mathrm{Ce} / \mathrm{Pb}$ signatures. In general, a greater influence of host rock partial melts is related to the weakly silica-undersaturated potassic series.

A phlogopite-bearing carbonate-metasomatized heterogeneous peridotite source responds for the main chemical variation in the least contaminated samples of each series. Metasomatic events could have generated a veined structure and modified the chemical and modal composition of the mantle source. Therefore, the high $\mathrm{CaO} / \mathrm{Al}_{2} \mathrm{O}_{3}$ and $\mathrm{La} / \mathrm{Zr}$ and the lower Ti/ Eu ratios as compared with those of primitive mantle compositions, together with $\mathrm{K}$-, Zr-, Hf- and Ti-negative anomalies in the primitive-mantle normalized spidergrams found for the strongly alkaline series of sodic character are thought as representative of a greater contribution of carbonated pyroxene-rich veins to the heterogeneous mantle source.

New Ar-Ar data for biotite of a tephriphonolite dike yielded an average age of $85.4 \pm 0.4 \mathrm{Ma}$. Such a value confirms the chronogroup $>80 \mathrm{Ma}$ for the inland SMAP occurrences and, together with other analytical results, go against the age progression hypothesis of an ESE migration of the proposed Trindade mantle plume model.

\section{ACKNOWLEDGMENTS}

Research funds for the present study were granted by Fundação de Amparo à Pesquisa do Estado de São Paulo FAPESP (Grants 2010/20425-8, 2017/03768-8, RGA; 2012/06082-6, ER; 2016/23399-4, CBG).

\section{SUPPLEMENTARY DATA}

Supplementary data associated with this article can be found in the online version: Suplementary Table A1, Suplementary Tables A2-A5 and Suplementary Table A6.

\section{REFERENCES}

Ablay G.J., Carroll M.R., Palmer M.R., Martí J., Sparks R.S.J. 1998. Basanite-phonolite lineages of the Teide-Pico Viejo volcanic complex, Tenerife, Canary Islands. Journal of Petrology, 39(5):905-936

Adam J. \& Green T. 2003. The influence of pressure, mineral composition and water on trace element partitioning between clinopyroxene, amphibole and basanitic melts. European Journal of Mineralogy, 15(5):831-841.

Albarède F. 1995. Introduction to Geochemical Modeling, Cambridge University Press. 543p

Almeida F.F.M. 1983. Relações tectônicas das rochas alcalinas mesozóicas da região meridional da plataforma sul-americana. Revista Brasileira de Geociências, 13(3):139-158.

Almeida F.F.M. 1986. Distribuição regional e relações tectônicas do magmatismo pós-paleozóico no Brasil. Revista Brasileira de Geociências, 16:325-349.
Alves F.R. 1978. Nota sobre o corpo gabróide de Sapucaí Mirim, SP/MG. Congresso Brasileiro de Geologia. Recife, Resumo dos Trabalhos, p. 95.

Alves F.R., Ruberti E., Vlach S.R.F. 1992. Magmatismo mesocenozóico da região da Serra da Mantiqueira, SP/MG. Boletim IGUSP, Publicação Especial, 12:7-9.

Araújo A., Carlson R.W., Gaspar J.C., Bizzi L.A. 2001. Petrology of kamafugites and kimberlites from the Alto Paranaiba alkaline province, Minas Gerais, Brazil. Contributions to Mineralogy and Petrology, 142(2):163-177.

Avanzinelli R., Bindi L., Menchetti S., Conticelli, S. (2004). Crystallisation and genesis of peralkaline magmas from Pantelleria Volcano, Italy: An integrated petrological and crystal-chemical study. Lithos, 73(1-2):41-69.

Azzone R.G. 2008. Petrogênese do maciço alcalino máfico-ultramáfico Ponte Nova (SP-MG). PhD Thesis, Universidade de São Paulo, São Paulo, $240 \mathrm{p}$. 
Azzone R.G., Enrich G.E.R., Gomes C.B., Ruberti E. 2013. Trace element composition of parental magmas from mafic-ultramafic cumulates determined by in situ mineral analyses: The Juquiá mafic-ultramafic alkaline-carbonatite massif, SE Brazil. Journal of South American Earth Sciences 41:5-21.

Azzone R.G., Munoz P.M., Enrich G.E.R, Alves A., Ruberti E., Gomes C.B. 2016. Petrographic, geochemical and isotopic evidence of crustal assimilation processes in the Ponte Nova alkaline maficultramafic massif, SE Brazil. Lithos, 260:58-75.

Azzone R.G., Ruberti E., Enrich G.E.R., Gomes C.B. 2009. Geologia e geocronologia do maciço alcalino máfico-ultramáfico Ponte Nova (SP-MG). Geologia USP Série Científica, 9(2):23-46.

Bastin G.F., Van Loo F.J.J., Heijligers H.J.M. 1984. Evaluation and use of gaussian $\Phi(\rho z)$ curves in quantitative electron probe microanalysis: a new optimization. X-Ray Spectrometry, 13:91-97.

Baudouin C. \& Parat F. 2015. Role of volatiles (S, Cl, $\mathrm{H}_{2} \mathrm{O}$ ) and silica activity on the crystallization of haüyne and nosean in phonolitic magmas (Eifel, Germany and Saghro, Morocco). American Mineralogist, 100(10):2308-2322.

Beccaluva L., Barbieri M., Born H., Brotzu P., Coltorti M., Conte A., Garbarino C., Gomes C.B., Acciotta M., Morbidelli L., Ruberti E., Siena F., Traversa G. 1992. Fractional crystallization and liquid immiscibility processes in the alkaline-carbonatite complex of Juquiá (São Paulo, Brazil). Journal of Petrology, 33(6):1371-1404.

Bellieni G., Montes-Lauar C.R., De Min A., Piccirillo E.M., Cavazzini G., Melf A.J., Pacca I.G. 1990. Early and Late Cretaceous magmatism from São Sebastião island (SE-Brazil): geochemistry and petrology. Geochimica Brasiliensis, 4(1):59-83.

Bennio L., Brotzu P., Gomes C.B., D’Antonio M., Lustrino M., Melluso L., Morbidelli L., Ruberti E. 2002. Petrological, geochemical and Sr$\mathrm{Nd}$ isotopic features of alkaline rocks from the Arraial do Cabo Frio peninsula (southeastern Brazil). Periodico di Mineralogia, 71(2):137-158.

Berger J., Ennih N., Liégeois J.P. 2014. Extreme trace elements fractionation in Cenozoic nephelinites and phonolites from the Moroccan Anti-Atlas (Eastern Saghro). Lithos, 210-211:69-88.

Brod J.A., Barbosa E.S.R., Junqueira-Brod T.C. Gaspar J.C., Diniz-Pinto H.S., Sgarbi P.B.A., Petrinovic L.A. 2005. The Late-Cretaceous Goiás Alkaline Province (GAP), Central Brazil. In: Comin-Chiaramonti P. and Gomes C.B. (eds.). Mesozoic to Cenozoic Alkaline Magmatism in the Brazilian Platform. São Paulo, Edusp/Fapesp, p. 261-340.

Brotzu P., Barbieri M., Beccaluva L., Garbarino C., Gomes C.B., Macciotta G., Melluso L., Morbidelli L., Ruberti E., Sígolo J.B., Traversa G. 1992. Petrology and geochemistry of the Passa Quatro alkaline complex, southeastern Brazil. Journal of South American Earth Sciences, 6(4):237-252.

Brotzu P., Beccaluva L., Conte A.M., Fonseca M., Garbarino C., Gomes C.B., Leong R., Macciotta G., Mansur R.L., Melluso L., Morbidelli L., Ruberti E., Sígolo J.B., Traversa G., Valença J.G. 1989. Petrological and geochemical studies of alkaline rocks from continental Brazil. 8. The syenitic intrusion of Morro Redondo, RJ. Geochimica Brasiliensis, 3(1):63-80.

Brotzu P., Gomes C.B., Melluso L., Morbidelli L., Morra V., Ruberti E. 1997. Petrogenesis of coexisting $\mathrm{SiO}_{2}$-undersaturated to $\mathrm{SiO}_{2}$ oversaturated felsic igneous rocks: The alkaline complex of Itatiaia, southeastern Brazil. Lithos, 40(2-4):133-156.

Brotzu P., Melluso L., Bennio L., Gomes C.B., Lustrino M., Morbidelli L, Morra V., Ruberti E., Tassinari C., D’Antonio M. 2007. Petrogenesis of the Early Cenozoic potassic alkaline complex of Morro de São João, southeastern Brazil. Journal of South American Earth Sciences, 24(1):93-115.

Brotzu P., Melluso L., D’Amelio F., Lustrino M. 2005. Potassic dykes and intrusions of the Serra do Mar Igneous Province (SE Brazil) In: Comin-Chiaramonti P., Gomes C.B. (eds.) Mesozoic to Cenozoic
Alkaline Magmatism in the Brazilian Platform. São Paulo, Edusp/ Fapesp, p. 443-472.

Cavalcante J.C., Cunha H.C.S., Chieregati L.A., Kaefer L.Q., Rocha J.M., Daitx E.C., Coutinho M.G.N., Yamamoto K., Drumond J.B.V., Rosa D.B., Ramalho R. 1979. Projeto Sapucaí: Relatório Final de Geologia. Série Geologia, n.5, Seção Geologia Básica, n.2, Brasília: DNPM/CPRM. 299p.

Chmyz L., Arnaud N., Biondi J.C., Azzone R.G., Bosch D., Ruberti E. (2017). $\mathrm{Ar}$-Ar ages, Sr-Nd isotope geochemistry, and implications for the origin of the silicate rocks of the Jacupiranga ultramafic-alkaline complex (Brazil). Journal of South American Earth Sciences, 77:286-309.

Clague D.A. 1987. Hawaiian alkaline volcanism. In: Fitton J.G. \& Upton B.G.J. Alkaline Igneous Rocks. Geological Society, 30, London, Special Publications, p. 227-252.

Comin-Chiaramonti P., Cundari A., Piccirillo E.M., Gomes C.B., Castorina F., Censi P., De Min A., Marzoli A., Speziale S., Velázquez V.F. 1997. Potassic and sodic igneous rocks from Eastern Paraguay: Their origin from the lithospheric mantle and genetic relationships with the associated Paraná flood tholeiites. Journal of Petrology, 38(4):495-528.

Comin-Chiaramonti P. \& Gomes C.B. 2005. Mesozoic to Cenozoic alkaline magmatism in the Brazilian Platform. São Paulo, Edusp/ Fapesp, 752p.

Dalton J.A. \& Wood B.J. 1993. The compositions of primary carbonate melts and their evolution through wallrock reaction in the mantle. Earth and Planetary Science Letters, 119(4):511-525.

Dasgupta R., Hirschmann M.M., Smith N.D. 2007. Partial melting experiments of peridotite $+\mathrm{CO}_{2}$ at $3 \mathrm{GPa}$ and genesis of alkalic ocean island basalts. Journal of Petrology, 48(11):2093-2124.

De La Roche H., Leterrier J., Grandclaude P., Marchal M. 1980. A classification of volcanic and plutonic rocks using $R_{1} R_{2}$-diagram and major-element analyses - Its relationships with current nomenclature. Chemical Geology, 29(1-4):183-210.

Enrich G.E.R. 2005. Petrogênese da suíte alcalina da Ilha Monte de Trigo, SP. PhD Thesis, Instituto de Geociências, Universidade de São Paulo, São Paulo, 229 p.

Enrich G.E.R., Ruberti E., Gomes C.B. 2009. Geology and geochronology of Monte de Trigo island alkaline suite, southeastern Brazil. Revista Brasileira de Geociências, 39(1):67-80.

Fitton J.G. \& Upton B.G.J. 1987. Alkaline igneous rocks. Geological Society Special Publication, 30, 568p.

Foley, S. 1992. Vein-plus-wall-rock melting mechanisms in the lithosphere and the origin of potassic alkaline magmas. Lithos, 28(3-6):435-453.

Furman T. \& Graham D. 1999. Erosion of lithospheric mantle beneath the East African Rift system: Geochemical evidence from the Kivu volcanic province. Lithos, 48(1-4):237-262.

Garda G., Schorscher J.H.D., Esperança S., Carlson R.W. 1995. The petrology and geochemistry of coastal dikes from São Paulo State, Brazil: Implication for variable litospheric contributions to alkaline magmas from the Western margins of the South Atlantic. Anais Academia Brasileira de Ciências, 67(2):191-216.

Gibson S.A., Thompson R.N., Leonardos O.H., Dickin A.P., Mitchell J.G. 1995. The Late Cretaceous impact of the Trindade mantle plume: Evidence from large-volume, mafic potassic magmatism in SE Brazil. Journal of Petrology, 36(1):189-229.

Gibson S.A., Thompson R.N., Leonardos O.H., Dickin A.P., Mitchell J.G. 1999. The limited extent of plume-lithosphere interactions during continental flood-basalt genesis: Geochemical evidence from Cretaceous magmatism in southern Brazil. Contributions to Mineralogy and Petrology, 137(1-2):147-169. 
Gibson S.A., Thompson R.N., Day J.A. 2006. Timescales and mechanisms of plume - lithosphere interactions: ${ }^{40} \mathrm{Ar} /{ }^{39} \mathrm{Ar}$ geochronology and geochemistry of alkaline igneous rocks from the Paraná-Etendeka large igneous province. Earth and Planetary Science Letters, 251(1-2):1-17.

Gomes C.B., Alves F.R., Azzone R.G., Rojas G.E.E., Ruberti E. 2017. Geochemistry and petrology of the Buzios Island alkaline massif, SE, Brazil. Brazilian Journal of Geology, 47(1):127-145.

Gomes C.B. \& Comin-Chiaramonti P. 2005. An introduction to the alkaline and alkaline-carbonatitic magmatism in and around the Paraná-Basin. In: Comin-Chiaramonti P., Gomes C.B. (eds.) Mesozoic to Cenozoic alkaline magmatism in the Brazilian Platform. São Paulo, Edusp/Fapesp, p. 21-30.

Green D.H., Schmidt M.W., Hibberson W.O. 2004. Island-arc ankaramites: Primitive melts from fluxed refractory lherzolitic mantle. Journal of Petrology, 45(2):391-403.

Green T.H., Blundy J.D., Adam J., Yaxley G.M. 2000. SIMS determination of trace element partition coefficients between garnet, clinopyroxene and hydrous basaltic liquids at 2-7.5 GPa and 1080-1200C. Lithos, 53:165-187.

Green D.H. \& Wallace M.E. 1988. Mantle metasomatism by ephemeral carbonatite melts. Nature, 336: 459-462.

Guarino V., Wu F.Y., Lustrino M., Melluso L., Brotzu P., Gomes C.B., Ruberti E., Tassinari C.C.G., Svisero D.P. 2013. U-Pb ages, Sr-Ndisotope geochemistry, and petrogenesis of kimberlites, kamafugites and phlogopite-picrites of the Alto Paranaiba Igneous Province, Brazil. Chemical Geology, 353:65-82

Heilbron M. \& Machado N. 2003. Timing of terrane accretion in the Neoproterozoic-Eopaleozoic Ribeira orogen (SE Brazil). Precambrian Research, 125(1-2):87-112

Heilbron M., Pedrosa-Soares A.C., Campos Neto M.C., Silva L.C., Trouw R.A.J., Janasi V.A. 2004. Província Mantiqueira. In: MantessoNeto V., Bartorelli A., Carneiro, C.D.R., Brito-Neves B.B. (eds.) Geologia do Continente Sul-Americano: evolução da obra de Fernando Flávio Marques de Almeida. São Paulo, Becca, p. 203-235.

Hirschmann M.M., Kogiso T., Baker M.B., Stolper E.M. 2003. Alkalic magmas generated by partial melting of garnet pyroxenite. Geology, 31(6):481-484

Hoernle K., Tilton G., LeBas M.J, Duggen S., Garbe-Schönberg D. 2002. Geochemistry of oceanic carbonatites compared with continental carbonatites: Mantle recycling of oceanic crustal carbonate. Contributions to Mineralogy and Petrology, 142(5):520-542.

Irvine T.N. \& Baragar W.R.A. 1971. A guide to chemical classification of the common volcanic rocks. Canadian Journal of Earth Sciences, 8(5):523-548.

Koppers A.A.P. 2002. ArArCALC - software for ${ }^{40} \mathrm{Ar} /{ }^{39} \mathrm{Ar}$ age calculations. Computers \& Geosciences, 28(5):605-619.

Le Maitre R.W. 2002. Igneous Rocks: A Classification and Glossary of Terms, second ed. Cambridge University Press, Cambridge.

Leake B.E., Woolley A.R., Arps C.E.S., Birch W.D., Gilbert M.C., Grice J.D., Hawthorne E., Kato A., Kirsch H.J., Krivovichev V.G., Linthout K., Laird J., Mandarino J., Maresch W.V., Nickel E.H., Rock N.M.S., Schumacher J.C., Smith D.C., Stephenson N.C.N., Ungaretti L., Whittaker E.J.W., Youzhi G. 1997. Nomenclature of amphiboles. Report of the Subcommittee on Amphiboles of the International Mineralogical Association Commission on New Minerals and Mineral Names. European Journal of Mineralogy, 9(3):623-651.

Legendre C., Maury R.C., Caroff M., Guillou H., Cotten J., Chauvel C., Bollinger C., Hemond C., Guille G., Blais S., Rossi P., Savanier D. 2005. Origin of exceptionally abundant phonolites on Ua Pou Island
(Marquesas, French Polynesia): Partial melting of basanites followed by crustal contamination. Journal of Petrology, 46(9):1925-1962.

Marques L.S., Dupré B., Piccirillo E.M. 1999. Mantle source compositions of the Paraná Magmatic Province (southern Brazil): Evidence from trace element and $\mathrm{Sr}-\mathrm{Nd}-\mathrm{Pb}$ isotope geochemistry. Journal of Geodynamics, 28:439-458

McDonough W.F. \& Sun S. 1995. The composition of the Earth Chemical Geology, 120(3-4):223-253.

Melcher G.C. \& Melcher B.A. 1972. Novas ocorrências de rochas alcalinas no estado de São Paulo. In: Congresso Brasileiro de Geologia. Belém, Resumo das Comunicações, p. 216-217.

Melluso L., Guarino V., Lustrino M., Morra V., Gennaro R. 2017. The REE- and HFSE-bearing phases in the Itatiaia alkaline complex (Brazil) and geochemical evolution of feldspar-rich felsic melts. Mineralogical Magazine, 81(2):217-250.

Menezes S.G., Azzone R.G., Rojas G.E.E., Ruberti E., Cagliarani R. Gomes C.B., Chmyz L. 2015. The antecryst compositional influence on Cretaceous alkaline lamprophyre dykes, SE Brazil. Brazilian Journal of Geology, 45(1):79-93.

Middlemost E.A.K. 1975. The basalt clan. Earth-Science Reviews, $11(4): 337-364$

Moore K.R. \& Wood B.J. 1998. The transition from carbonate to silicate melts in the $\mathrm{CaO}-\mathrm{MgO}-\mathrm{SiO}_{2}-\mathrm{CO}_{2}$ system. Journal of Petrology, 39(11-12):1943-1951.

Morbidelli L., Gomes C.B., Beccaluva L., Brotzu P., Conte A.M., Ruberti E., Traversa G. 1995. Mineralogical, petrological and geochemical aspects of alkaline and alkaline-carbonatite associations from Brazil. Earth-Sciences Review, 39(3-4):135-168

Mori P.E., Correia C.T., Reeves S., Haukka M. 1999. Development of a fused glass disc XRF facility and comparison with the pressed powder pellet technique at Instituto de Geociências, São Paulo University, Brazil. Revista Brasileira de Geociências, 29(3):441-446.

Morimoto N., Fabries J., Ferguson A.K., Ginzburg I.V., Ross M., Seifert F.A., Zussman J., Aoki K., Gottardi G. 1988. Nomenclature of pyroxenes. Mineralogical Magazine, 52:535-550.

Motoki A. 1986. Geologia e petrologia do maciço alcalino da Ilha de Vitória, SP. PhD Thesis, Instituto de Geociências, Universidade de São Paulo, São Paulo, 245 p.

Navarro M.S, Andrade S., Ulbrich H.H.J., Girardi V.A.V. 2008. The analysis of rare earth elements with ICP-MS in basaltic and related rocks: testing the efficiency of sample decomposition procedures. Geostandards and Geoanalytical Research, 32:167-180.

Orejana D., Villaseca C., Billström K., Paterson B.A. 2008. Petrogenesis of Permian alkaline lamprophyres and diabases from the Spanish Central System and their geodynamic context within Western Europe. Contributions to Mineralogy and Petrology, 156(4):477-500.

Petronilho L.A. 2009. Método Sm-Nd no CPGeo-IGc-USP. procedimentos analíticos atualmente em rotina. In: Simpósio 45 anos de Geocronologia no Brasil, Boletim de Resumos Expandidos, 116-118.

Phillips D. \& Matchan,E.L. 2013. Ultra-high precision ${ }^{40} \mathrm{Ar} /{ }^{39} \mathrm{Ar}$ ages for Fish Canyon Tuff and Alder Creek Rhyolite sanidine: New dating standards required? Geochimica et Cosmochimica Acta, 121:229-239.

Regelous M. (1993). Geochemistry of dolerites from the Paraná flood basalt province, southern Brazil. PhD Thesis, Open University, Milton Keynes, UK, $256 \mathrm{p}$

Reiners P.W., Nelson B.K., Ghiorso M.S. 1995. Assimilation of felsic crust by basaltic magma: Thermal limits and extents of crustal contamination of mantle-derived magmas. Geology, 23(6):563-566. 
Riccomini C., Velázquez V.F., Gomes C.B. 2005. Tectonic controls of the Mesozoic and Cenozoic alkaline magmatism in the centralsoutheastern Brazilian Platform. In: Comin-Chiaramonti P. \& Gomes C.B. (eds.) Mesozoic to Cenozoic alkaline magmatism in the Brazilian Platform. São Paulo. Edusp/Fapesp, p. 31-56.

Rosa P.A. \& Ruberti E. 2017. Nepheline syenites to syenites and granitic rocks from the Itatiaia alkaline massif, SE Brazil: New geological insights of a migratory ring complex Brazilian Journal of Geology, submitted.

Ruberti E., Rojas G.E.E., Azzone R.G., Comin-Chiaramonti P., de Min A., Gomes C. 2012. The Banhadão alkaline complex, southeastern Brazil: Source and evolution of potassic $\mathrm{SiO}_{2}$-undersaturated high-Ca and low-Ca magmatic series. Mineralogy and Petrology, 104:63-80.

Rudnick R.L., McDonough W.F., Chappell B.W. 1993. Carbonatite metasomatism in the northern Tanzanian mantle: Petrographic and geochemical characteristics. Earth and Planetary Science Letters, 114(4):463-475.

Sato E.N., Vlach S.R.F., Basei M.A.S. 2008. Zircon and baddeleyite $\mathrm{U}-\mathrm{Pb}$ dating (TIMS) of Mesozoic alkaline rocks from the São Sebastião Island, southeastern Brazil. In: 33nd International Geological Congress, Oslo, Abstracts, CD-ROM.

Souza S.L. 2009. Métodos radiométricos Rb-Sr e Sm-Nd no CPGeoIGc-USP. In: Simpósio 45 anos de Geocronologia no Brasil, Boletim de Resumos Expandidos, 137-139.

Stracke A. 2012. Earth's heterogeneous mantle: A product of convection-driven interaction between crust and mantle. Chemical Geology, 330-331:274-299.

Tegner C., Wilson J.R., Robins B. 2005. Crustal assimilation in basalt and jotunite: Constraints from layered intrusions. Lithos, 83(3-4):299-316

Tello-Saenz C.A., Hackspacher P.C., Hadler Neto J.C., Iunes P.J., Guedes S., Ribeiro L.F.B., Paulo S.R. 2003. Recognition of Cretaceous, Paleocene, and Neogene tectonic reactivation through apatite fission-track analysis in Precambrian areas of southeast Brazil: Association with the opening of the south Atlantic Ocean. Journal of South American Earth Sciences, 15(7):765-774

Thompson G., Smith I., Malpas J. 2001. Origin of oceanic phonolites by crystal fractionation and the problem of the Daly gap: An example from Rarotonga. Contributions to Mineralogy and Petrology, 142(3):336-346

Thompson R.N., Gibson S.A., Mitchell J.G., Dickin A.P., Leonardos O.H., Brod J.A., Greenwood J.C. 1998. Migrating Cretaceous-Eocene Magmatism in the Serra do Mar Alkaline Province, SE Brasil: Melts from the Deflected Trindade Mantle Plume?. Journal of Petrology, 39(8):1493-1526.

Tischendorf G., Förster H.-J., Gottesmann B., Rieder M. 2007. True and brittle micas: Composition and solid-solution series. Mineralogical Magazine, 71(3):285-320.
Traversa G., Barbieri M., Beccaluva L., Coltorti M., Conte A.M., Garbarino C., Gomes C.B., Macciotta G., Morbidelli L., Ronca S., Scheibe L.F. 1996. Mantle sources and differentiation of alkaline magmatic suite of Lages, Santa Catarina, Brazil. European Journal of Mineralogy, 8(1):193-208.

Ubide T., Arranz E., Lago M., Galé C., Larrea P. 2012. The influence of crystal settling on the compositional zoning of a thin lamprophyre sill: A multi-method approach. Lithos, 132-133: 37-49.

Ubide T., Galé C., Larrea P., Arranz E., Lago M. 2014. Antecrysts and their effect on rock compositions: The Cretaceous lamprophyre suite in the Catalonian Coastal Ranges (NE Spain). Lithos, 206-207:214-233.

Ulbrich H.H.G.J. \& Gomes C.B. 1981. Alkaline rocks from continental Brazil. Earth-Science Reviews, 17(1-2):135-154

Ulbrich H.H.G.J., Vlach S.R.F., Demaiffe D., Ulbrich M.N.C. 2005. Structure and origin of the Poços de Caldas Alkaline Massif, SE Brazil. In: Comin-Chiaramonti P., \& Gomes C.B. (eds.) Mesozoic to Cenozoic Alkaline Magmatism in the Brasilian Plataform. São Paulo, Edusp/Fapesp, p. 367-418

Valente S.C. 1997. Geochemical and isotopic constraints on the petrogenesis of the cretaceous dykes of Rio de Janeiro, Brazil. PhD Thesis, Queen's University of Belfast, 366 p.

Vinagre R., Trouw R.A.J., Mendes J.C., Duffles P., Peternel R., Matos G. 2014a. New evidence of a magmatic arc in the southern Brasília Belt, Brazil: The Serra da Água Limpa batholith (Socorro-Guaxupé Nappe). Journal of South American Earth Science, 54:120-139.

Vinagre R., Trouw R.A.J., Mendes J.C., Ludka, I. 2014b. Química mineral e geotermobarometria do Batólito Serra da Água Limpa, Nappe Socorro-Guaxupé, Faixa Brasília Meridional, Sudeste do Brasil. Brazilian Journal of Geology 44(3):387-414.

Wilson M., Downes H., Cebriá J.M. 1995. Contrasting Fractionation Trends in Coexisting Continental Alkaline Magma Series; Cantal, Massif Central, France. Journal of Petrology, 36(6):1729-1753.

Yaxley G.M., Crawford A.J., Green D.H. 1991. Evidence for carbonatite metasomatism in spinel peridotite xenoliths from western Victoria, Australia. Earth and Planetary Science Letters, 107(2):305-317.

Yaxley G.M., Green D.H., Kamenetsky V. 1998. Carbonatite metasomatism in the southeastern Australian lithosphere. Journal of Petrology, 39(11-12):1917-1930.

Zanetti A., Tiepolo M., Oberti R., Vannucci R. 2004. Trace-element partitioning in olivine: Modeling of a complete data set from a synthetic hydrous basanite melt. Lithos, 75(1-2):39-54.

Zeng G., Chen L., Xu X., Jiang S., Hofmann A.W. 2010. Carbonated mantle sources for Cenozoic intra-plate alkaline basalts in Shandong, North China. Chemical Geology, 273(1-2):35-45. 